\title{
Böske Simon, Miss Hungaria and Miss Europa (1929): Beauty Pageants and Packaging Gender, Race, and National Identity in Interwar Hungary
}

\section{Louise O. Vasvári}

Abstract: In this interdisciplinary article that draws on the intersections of Hungarian and Jewish Studies within a framework of cultural studies and gender studies, Louise O. Vasvári investigates the socio-political role of beauty pageants in 1920s European andmore specifically - in Hungarian social, political and cultural life. The article is structured as a case study of the life of Böske Simon, who was born into a bourgeois Jewish family in 1909 and who won the first Miss Hungaria competition in 1929, soon followed by the title of Miss Europa. Vasvári aims to place Simon's role as Hungarian beauty queen in a broader focus by examining from a gender perspective the international development of beauty pageants, of the illustrated press, and of commercial beauty culture in the 1920s. She examines the symbolic space allotted to the concept "Modern Girl," who in the interwar [re]construction of gender and national identities came to represent both the enticements and the dangers of modernity. More specifically, she examines how the problematic gender representation of women in such pageants and their reception by the press and by the public interact in the broader interwar nationalistic cultural sphere in postTrianon Hungary.

Keywords: Beauty pageants, post-Trianon Hungary, interwar modernity, Lisl Goldarbeiter, Zsazsa Gabor, the Modern Girl, beauty culture, Szinházi élet, Maurice de Waleffe, Sándor Incze, illustrated magazines

Biography: Louise O. Vasvári (M.A. and Ph.D., UC, Berkeley) is Professor Emerita of Comparative Literature and of Linguistics at Stony Brook University. Currently she teaches in the Linguistics Department at NYU and is also Affiliated Professor at the University of Szeged. She works in medieval studies, diachronic and sociolinguistics, Holocaust studies, and Hungarian Studies, all informed by gender theory within a broader framework of comparative cultural studies. In relation to Hungarian Cultural Studies she has published numerous articles, as well as, with Steven Tötösy, Imre Kertész and Holocaust Literature (2005), Comparative Central European Holocaust Studies (2009), and Comparative Hungarian Cultural Studies (2011). During the academic year 2014-2015 she was

* I thank the Institute of Advanced Study, Central European University, Budapest, where as a Senior Fellow from 2014 to 2015 I was able to read many of the sources I rely upon here. I also thank Corina Petrescu, my colleague in IAS during that period, and Ilana Rosen for their invaluable help. 
Senior Research Fellow at the Institute of Advanced Studies at the Central European University.* She is also an elected member of the Hungarian Szépírók Társasága and since 2011 Editor-in-Chief of Hungarian Cultural Studies. louise.vasvari@stonybrook.edu

\section{Böske Simon, Miss Hungaria and Miss Europa 1929.}

When in 1929 twenty-year old Böske Simon (February 15, 1909 - October 28, 1970) was chosen as the very first Miss Magyarország/Miss Hungária only to win the title of Miss Europa a few weeks later, she was briefly celebrated in both print media (especially in the new genre of the illustrated magazine) and in the even newer genre of the newsreel on a level that extended beyond Hungary to spread throughout Europe and then reach worldwide proportions. Beginning my study with an analysis of Simon's life, I aim to investigate the gendered socio-cultural meaning that beauty contests had in the incipiently modernist American and European, and more specifically, Hungarian culture of the 1920s. I will focus on the differing reception of Simon's victory by the Hungarian press and public, both on the political left and on the right.

Since Simon lived out her life in obscurity after her brief stint in the public eye and endured persecution from 1944, followed by lifelong tragedy, I must begin with an overview of her life as examined from the socio-political context of interwar Hungary, itself characterized by a traumatic national identity. In the interwar period the dismemberment of the major part of historic Hungary in the 1920 Trianon Peace Treaty, followed by two failed revolutions (a liberalsocialist and a communist) as well as a counterrevolution, led to the total domination of Trianon's trauma in Hungarian politics. As Steven Béla Várdy (1983: 22) eloquently put it, Horthy's interwar regime was determined "almost exclusively by the psychological shock of Trianon and the overriding desire to undo the treaty [which] was so pervasive and so heavily felt that the syndrome it produced can only be compared to a malignant national disease."

Böske Simon was born in 1909 to a bourgeois Jewish family who lived in Keszthely, a small city located on the western shores of Lake Balaton. At the time of his daughter's victory, her physician father, Sándor Simon (1870-1944), was the head of the Keszthely hospital, although he himself was of humble origin as the son of a butcher. As was the case at the time with many urilány ['a nubile young lady of a certain station'], and those aspiring to that status, Simon spent between age fifteen and sixteen at an elegant finishing school in Vienna, after which she attended another finishing school in Germany for a semester. In her miniautobiography she recounts how she arrived in Vienna as a provincial girl with her hair in braids and that it was from her more sophisticated classmates there that she learned to dress elegantly and wear silk stockings; unlike her classmates, she did not yet get her hair bobbed or wear any makeup. Like girls of her class, she dabbled in learning foreign languages and practiced lady-like sports such as tennis, but she received no training in any trade or profession. Nor did she attend school beyond the age of sixteen, but rather waited at home for the proverbial proper suitor.

\footnotetext{
* I thank the Institute of Advanced Study, Central European University, Budapest, where as a Senior Fellow from 2014 to 2015 I was able to read many of the sources I rely upon here. I also thank Corina Petrescu, my colleague in IAS during that period, and Ilana Rosen for their invaluable help.
} 
Blond, blue-eyed and svelte, Böske started her beauty career in 1924 as the Keszthelyi Korzó Szépe ['the belle of Keszthely'], a competition in which the winner was chosen only on the basis of photos. Following this she also won the local title of Balaton Tündére ['The Siren of Balaton'], an actual live beauty contest. Both contests were organized by Sándor Incze, the editor of the popular illustrated weekly, Szinházi élet ['Theater Life']. In late 1928, Incze announced the first Miss Magyarország contest at the behest of the editor of a Parisian newspaper owner, Maurice de Waleffe, one of the first promoters of beauty contests. (The more detailed history of the rise of beauty contests in the 1920s and specifically of the first Hungarian contest will be discussed in the second section of this article, including how such contests were used to give the beauty industry and illustrated popular journalism a respected, albeit commercial image.)

In January 1929, Simon won the first Miss Magyarország contest, held in the editorial offices of Szinházi élet in Budapest. According to the fawning report published in that magazine, all the preparation Simon did for the competition was to put on lipstick for the first time, following a girlfriend's direction. Here we see an official photo of Böske Simon as the first Miss Magyarország, dressed in a conservative, high-necked outfit with lace collar and cuffs, with her hands demurely crossed:

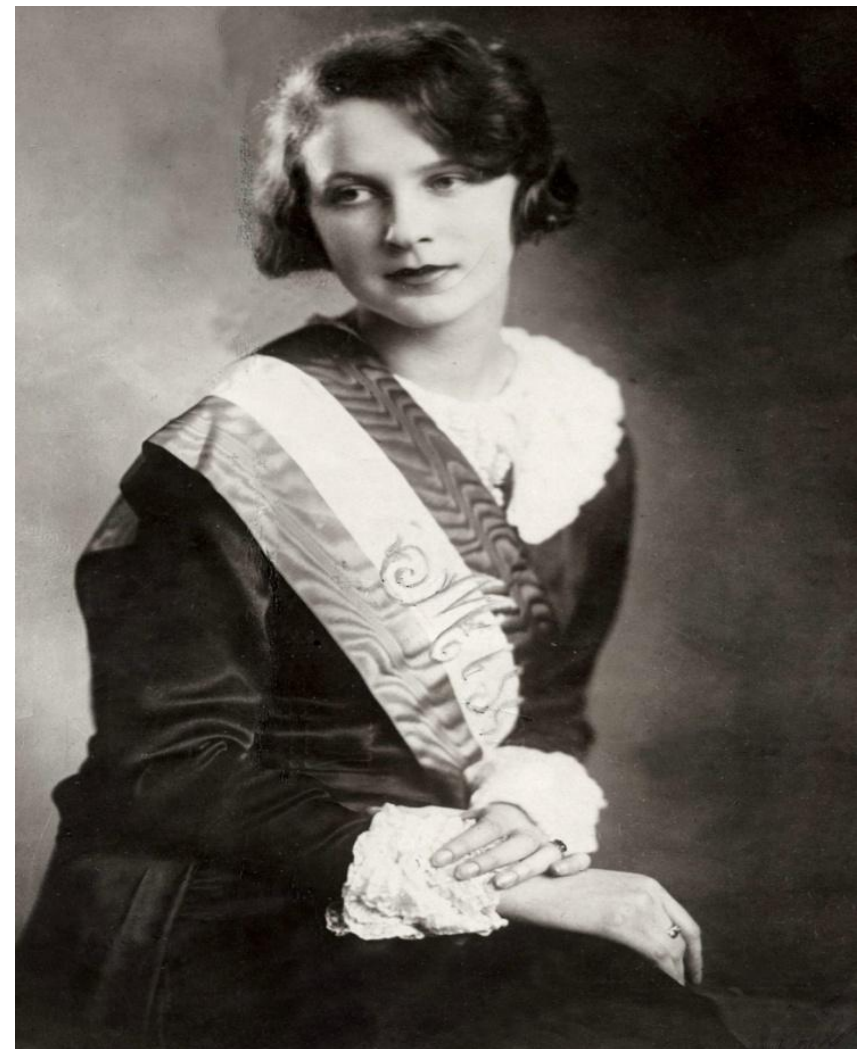

On February 2, 1929, the new Miss Hungaria, accompanied by her mother and Sándor Incze, traveled to Paris to take part in the second Miss Europa contest. There Simon was taken under the wing of the celebrated Hungarian-American twin entertainers, the Dolly Sisters, Jenny/Dzeni 'Jancsi' Dolly (1892-1941), who provided Simon with outfits from the exalted French designer, Jean Patou, sent her hairdressers, cosmeticians and arranged to have her dressed 
from head to toe in preparation for the contest. Incze also had an ongoing relationship with the Dolly sisters during this period as he published their illustrated life story in segments throughout several issues in 1929. In spite of the careful grooming Jenny Dolly provided Simon, Szinházi élet once again reported the news that Simon was supposedly again the only contestant in Miss Europe contest who had not been wearing make-up. On February 7, 2019, while patriotically wearing the Hungarian cockade, Simon won the Miss Europa competition in Nice, triumphing over sixteen other European beauties (of which here is a British Pathé newsreel, featuring Simon in the foreground, with the organizer of the contests, Maurice de Waleffe, about whom more details in Section Two of this paper:

https://www.britishpathe.com/video/VLVA1JYB5W84AS5JJFYOFAWZJGUOA-FRANCELEISURE-BEAUTY-QUEEN-OF-EUROPE-CHOSEN-AT-NICE-CASINO/query/wildcard . Here is a photo of the glamorously dressed Simon as Miss Europa, flanked by Miss France, Germaine Laborde, on her left, and Miss Germania, Elisabeth Yvette Rodzyn, on her right. (The caption for this same photo in Szarka 2018 is incorrect because neither girl is Miss Romania, Marioara Ganesco, who is dark complexioned, and about whom see further below):

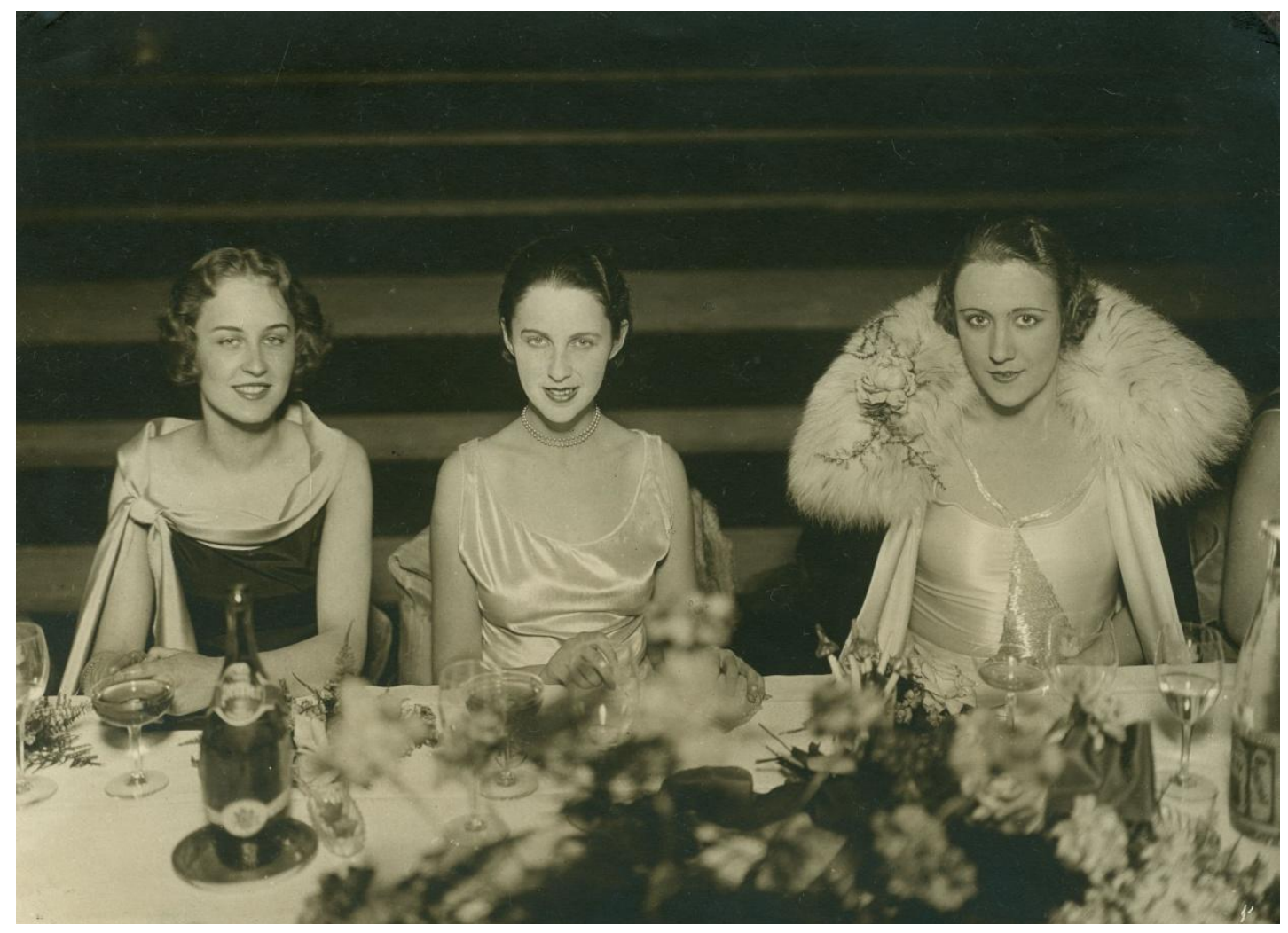

For weeks after the contest Simon was feted everywhere and was even received by the French Premier, the Prince of Monaco and the Prince of Wales. Other than these members of the aristocracy, she also met politicians, celebrities and artists while additionally receiving offers of marriage and contract proposals from both theaters and Hollywood. In spite of these opportunities, Böske repeatedly declared that while it had been a great honor to represent her homeland, she had no career ambitions. 
Throughout her year of reign Szinházi élet naturally put Simon on its cover over and over again and featured a number of saccharine stories about her (all of which can be read online at http://epa.oszk.hu/html/vgi/kardexlap.phtml?aktev=1929\&id=2343). Below is the colorized portrait featured on the cover of the February 18, 1929 issue, with Simon's blue eyes highlighted:

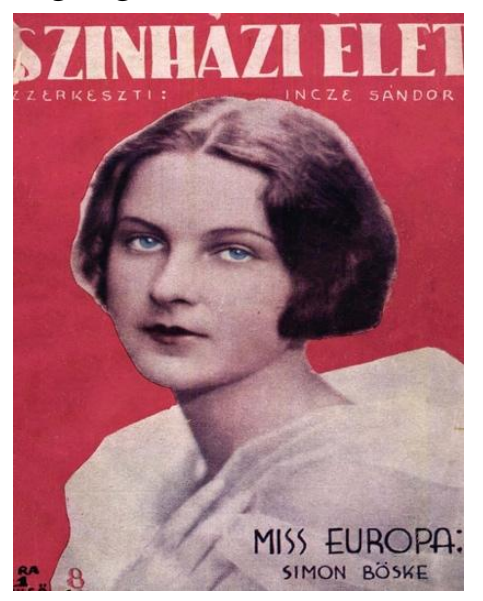

One example will have to suffice to illustrate the level of the reportage with which Böske Simon's success was followed in Szinházi élet. This particular article details how Miss Europa wanted to avoid further pomp, celebrations or public appearances and only longed to return to Hungary and her csöndes, vidéki magyar kisváros ['quiet provincial small town'], but could not afford to turn down a prestigious invitation to a state ball held in Geneva and therefore had to extend her stay abroad (1929.11.6). Newspapers on the political left as well as the right also reported on the new Hungarian Miss Europa; while some celebrated the fact that her victory meant that the world had finally paid attention to the postTrianon megalázott csonka Magyarország ['demeaned and crippled Hungary'], some rightist newspapers felt that the Jewish Simon could not represent Hungarian beauty; the pageant had therefore been an international Jewish conspiracy and better families would in any case not allow their daughters to participate in such an event (Szarka 2018: 35-49). Meanwhile, Szinházi élet published a supposedly humorous article by the famous writer Frigyes Karinthy, in which a jury of women suggest candidates for Mister Europa, including Mussolini, Bernard Shaw, Mosjoukine (a great Russian actor who lived in France), Conrad Veidt (a German actor), Simon Krausz (a rich Hungarian Jewish banker), the Prince of Wales, Landru (a French serial killer guillotined in 1922) and Albert Einstein.

Europe's Jewish press expressed its pride in Simon's win, such as in an article published by the German Jewish Israelitisches Familienblatt, the foremost non-party Jewish weekly in preHitler Germany which featured articles about prominent figures who openly acknowledged their Jewishness. The Familienblatt wrote that although Simon did not look stereotypically Jewish, she bekennt sich stolz auf ihrem Judentum ['declares herself to be proud of her Jewishness']. The paper also reported that Simon came from a religious Jewish home and reprinted a Parisian Jewish journalist's interview in which — when she was asked if she was Jewish-Simon replied yes, but that she was asked this question so often that it was becoming oppressive. At the same time, the Völkischer Beobachter, the paper of the National Socialist Party, called Simon a spoiled Judenmädel ['little Jewish girl'], who had fallen victim to French industrialists (Wallach 2017).

In Hungary the most influential and long-lasting Jewish periodical, Egyenlöség ['Equality'], an assimilationist liberal Hungarian language weekly that was published until 1938, wrote a series of laudatory articles about Simon which proposed, for example, that her success was similar to winning an Olympic gold, that she was a multilingual, cultured sportswoman and the daughter of an elökelö ['distinguished'] family with an elökelö social life in Keszthely, repeating the keyword, which was, in practice, a code word for not seeming Jewish. As proof of Simon's own Jewish feeling, the article similarly recounts how the year before at a ball in Tapolca when the son of a rich wine producer had asked for her hand she declared that she would not marry a kikeresztelkedett zsidó ['a Jew who had converted to Christianity'] (Feb. 16, 1929: 1). In an article in the following issue (Feb 23, 1929: 5) the same tone continued, 
explaining that the world press has been writing very favorably about Böske mint a magyar faj büszkeségéröl ['standing for the pride of the Magyar race'] because she was not only beautiful but finom, nemes vonalu arisztokratikus tartásu, elökelö mozgásu ['refined, with noble line, aristocratic bearing, and elegant movement']. The article went on to detail her nemes egyszerïség ['noble simplicity'] and report that she was considered the most beautiful among the fifty-four girls in her finishing school and known as the szöke magyar szépség ['beautiful blond Hungarian beauty'], who was also a serious student who had learned both German and English perfectly (a német es angol nyelvet tökéletessen elsajátitotta ['learned German and English perfectly']), while she also played tennis, swam, danced and did gymnastics.

All of the aforementioned articles do little more than repeat the code words elökelö, nemes, arisztokratikus, and finom, anxious to signal that Simon was gentile-acting and therefore able to pass in public as non-Jewish, akin to the Germany practice of referring to gentile-acting females as practicing vornehme Zürückhaltung ['genteel restraint'] (Wallach 2017: 11). It takes the one female author, one Dr. Baracs Marcellné in her article, Simon Böske gyermetegen bájos kék szeme lázba hozta Europát ['Böske Simon's Charming Naïve Eyes Fired Up Europe'] (March 9: 11), not only to assure readers that Simon could pass as non-Jewish but, as importantly, that she was a perfect specimen of femininity because she was without any ambition. Baracs first asserts that Simon's victory has brought glory to Hungarians and to Jews and to mothers, but that she is afraid that Simon's beautiful soul is in danger. The only photo of her that Baracs approves of is the one seen above, of Simon in a dress closed at the neck, a lace collar and cuffs her only embellishment, with her two hands folded together, her hair smoothly parted in the middle. This is, as the author describes, a photo in which we see only her, with no finery nor artifice, only the fact that a beautiful woman is noble and from God. This author's insistence on wanting Simon to present herself in a dowdy outfit is part of an inner-Jewish debate about fashion that raged in the 1920s between religious conservatives who believed that Jewish women should practice tznius 'modest dress' and resist imitating the revealing gentile fashion of the day, versus the liberal view that Jewish women should be free to participate in mainstream fashion. Not allowing them to do so was seen as tantamount to imposing antiSemitic restrictions (on Jewish fashion, see Wallace 2013: 124). Finally, Baracs expresses her faith in Simon as a paragon of womanhood since before leaving Keszthely she had reportedly told her friends bidding her farewell that ö semmi sem akar lenni ['she doesn't want to be anything']: not famous not important, only the happy wife of an appropriate husband.

While the Hungarian and German press were preoccupied with the intersection of racial and national identity in the figure of a Jewish Miss Europe, the critical reaction expressed in some of the international press tended to be more concerned about the commercial aspects of this type of international contest. Rather than focus on issues of race, for example, an article, "Miss Europe: Charm as a Commercial Asset," that appeared after Simon's victory characterized such beauty contests as the ludicrous commercial ventures they are. It pointed out that becoming a beauty queen had turned into a career; once elected "she becomes the puppet of scent, stocking, face cream, and shoe manufacturers, of talking and movie films." The article further objects that while these girls may have a "chocolate boite of prettiness" other truer beauties can be found on the streets of the capital cities of the countries they represent (Anonymous 1929). Another article complains that the universal vogue in hair dressing and the use of cosmetics and facial creams had made all seventeen Miss Europe contestants so standardized that the girls could have been pupils of a fashionable boarding school, with no detectable national difference among them. The 
article also claims that such contests also demonstrate that the classic lines of beauty have been forsaken as the modern eye demands slimness and petiteness above everything else. The article also adds that Miss Hungaria, who was selected as Miss Europe, presents nothing of magyar traits but is rather an amalgam that the continent regards as lovely (Warren1929: 2). While it is true that among the contestants only the youngest contestant, sixteen-year old Miss Helvetia, did not have bobbed hair, it is hardly true that none of the contestants looked distinctly ethnically different, as can be seen from a composite photo of all the contestants at https://multkor.hu/ime-a-16-lany-akiket-a-magyar-simon-bske-legyoztt-az-1929-es-miss-europa-versenyen20161207? openImage $=10274$. See below a photo of the six contestants and Böske Simon:

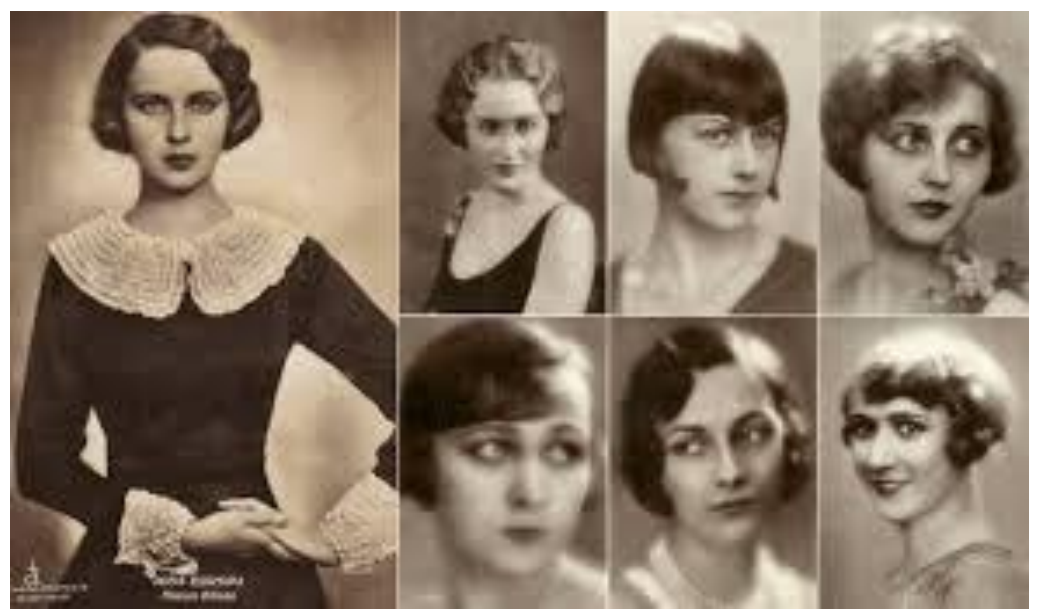

If the response of the Hungarian and international press to Simon's victory was mixed, so was her reception on her return to Budapest on March 13. Simon was initially received by a jubilant crowd of many hundreds as she arrived in a horse-drawn carriage decorated with flowers. Three orchestras played the national anthem and the mayor gave a speech congratulating her on her victory against delegates from Hungary's opponents in the Great War. In response, the tearful Simon could hardly speak, but briefly expressed her gratitude for the welcome and declared her pride in having been able to glorify her country.

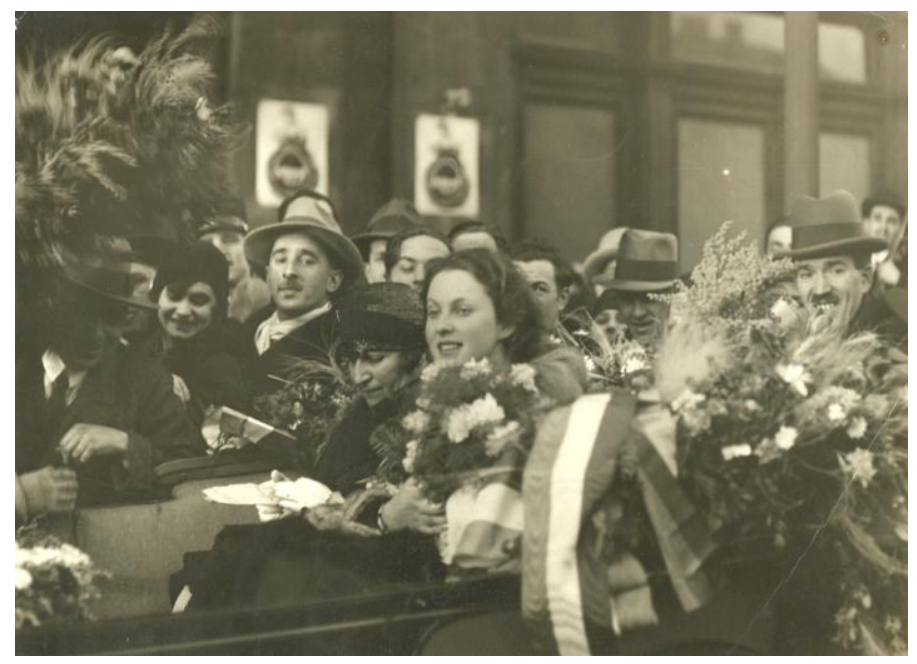


In spite of the cheering crowds that greeted the new Miss Europa upon her return to Hungary, as a Jewish Hungarian beauty queen Simon also faced a number of unpleasant incidents. Four days after her return, as she signed autographs for charity, she was verbally insulted by a large group rightist women, who shouted the insults of Miss Palestina and ronda zsidó lány, nem vagy magyar ['ugly Jewish girl, you're not Hungarian']. Later in her hometown of Keszthely, far-rightist students from the Magyar Királyi Gazdasági Akademia ['The Royal Hungarian Agricultural School'] whistled at her in derision. Members of the group later rioted outside her home and vandalized the cinema when it showed a newsreel depicting her reception by the Hungarian Legation in Vienne (The New York Times March 31, 1929). Neither of these events were random: they were instead organized political demonstrations, as the interwar period activities of social movements became highly politicized.

The women who heckled Simon represented the Magyar Asszonyok Nemzeti Szövetsége (MANSZ) ['The National Federation of Hungarian Women'], a rightist Christian woman's organization founded in January, 1919 by the best-selling writer of social novels and founder of Hungary's conservative women's movement, Cecile Tormay, under whose leadership the group counted about a half-million members. The group followed an explicitly anti-liberal and antiemancipatory ideology that was combined with nationalist, irredentist and anti-Semitic rhetoric. Its journal, A magyar nö ['The Hungarian Woman'], promoted traditional roles for women based on biological determinism and restrictions upon their employment. A complex and charismatic political figure, Tormay claimed that her movement was entirely "home-grown" in Hungary. In fact, her politics are better understood in the comparative perspective of the fascist aesthetic of reactionary modernism, specifically within the context of the complex psychosexual dynamics and artistic self-promotion of rightist interwar lesbian modernism (see further, Carlson 1998, Zox-Weaver 2011). Tormay was skilled in navigating the tensions between her modernist private life and her manufactured public image. Although she herself never married and lived only with women and was involved in a major homosexual legal scandal, she was reclaimed as Hungary's ideal patriotic female figure responsible for upholding traditional gender norms. The heckling episode of Simon is but one, illustrative example for understanding the right-wing nationalist women's movements that emerged in the aftermath of World War I, that succeeded in pushing other women's movements to the margins (see further, Passmore 2003, Weaver 2006: 20, Acsády 2014, Kurimay 2016, Szapor 2018)

Also establised in 1919 like MANSZ, The Turul Szervezet ['The Turul Association'], by the latter half of the 1920s kthe young male organization harassing Simon, had become the largest national student organization. Its so-called Christian-national ideology had many components, but mainly proclaimed a right-wing militarist, irredentist, anti-Semitic "racial defense" of Hungary. Turul members were regularly involved in massive protests against the Trianon Treaty; like similar interwar political organization in other countries, this organization held a radically conservative view on the role of women, were against women's emancipation and expressed a radical rejection of modernity. Regular student demonstrations figured among the significant expressions of Turul's anti-Semitic activities conducted at various universities, events which particularly increased after the easing of the 1920 numerus clausus in 1928 by Count István Bethlen. Turul members were also responsible for regular atrocities against Jewish colleagues, including occasionally attacks against female Jewish students, showing the emergence of masculine violence in their self-definition, cogently dubbed "national masculinity" by Róbert Kerepeszki (2014) in the title of his study on the movement. Turul members jeering at 
Böske Simon as both a Jew and a beauty queen was just the beginning: by 1931, the Turul chapter in Debrecen (later joined by other right-wing national organizations) issued a statement against beauty contests and announced a boycott against young women who participated in such commercial competitions. They deemed beauty contests to be against national morals and the proper role of women as modest wives and caring mothers (Kerepeszi 2014: 70). (The group later demonstrated against certain actresses, most notably against Katalin Karády, who often played femme fatale roles.)

In July, Simon returned to France; on August 7, 1929, in Deauville, she then won the European-held title of Miss Universe in a tie with Ella Van Hueson, Miss America. However, this title was of secondary importance because the more important competing Miss Universe competition was held in Galveston, Texas, which Simon did not attend. The founder of the Miss Europa competition, Maurice de Waleffe, explained in his memoir that this was due to the fact that the Americans invited forty-eight contestants from the US to the competition in Texas and only five or six from Europe. In objection to this inequality, Europe [meaning de Waleffe, as the organizer] decided to stay home and elect its own Miss Universe from among fifteen European beauties (Waleffe 1947: 447).

Szinházi élet reported on the Dauville contest in great detail (SzE 19.33, aug. 11-7), including a list of all the offers Simon received, from film contracts with Paramount and the Berlin Hegewald studio to invitations issued by American-Hungarians who wanted to organize Hungarian balls all over the US and have her attend. Even "4711" cologne wanted to offer her a five-year contract. The Dutch French painter, Kees Van Dongen, also invited Simon to Le Toquet to paint her, while one of the competition judges, the Maharadja of Kapurtalai, held a large dinner in her honor. The photos in Szinházi élet show enormous crowds that resemble those at the horse races of the period and the two winners parading in bathing suits on a catwalk. A particularly curious photo shows Foujita, the famous Japanese-French artist, also parading in a bathing suit on the catwalk; dubbed as an "outsider candidate" with no further explanation offered, the article turns a blind eye to the gender implications of Foujita's self-presentation. In the third photo below we see the two winners who tied for first place as Miss Universe in Dauville,

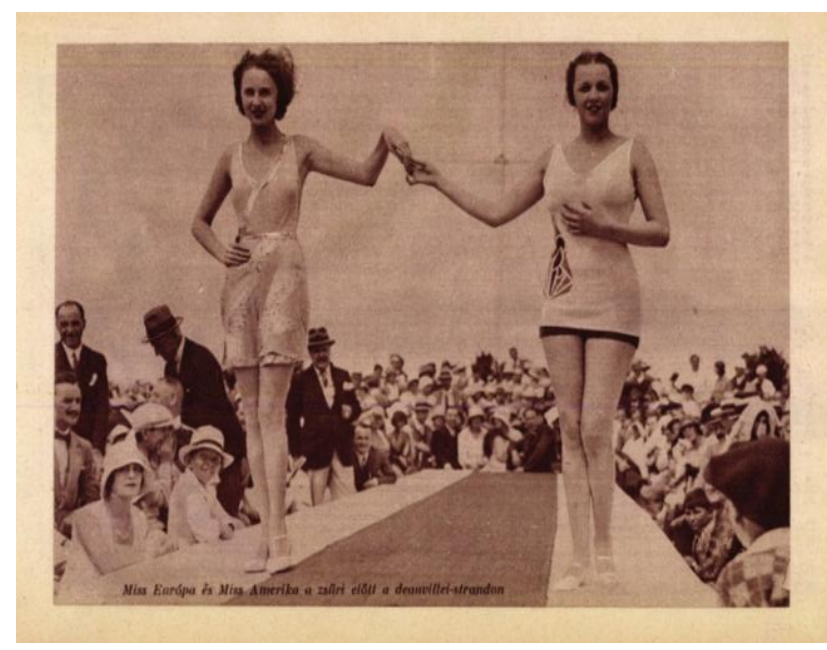
together with Maurice de Waleffe. In his memoir Waleffe again shares interesting comments about the two contestants, including that the more "Junoesque" American from Chicago was the clear favorite at first, but the Hungarian - deemed as classier, feistier and more high-strung - also won over the jury so that a tie finally had to be declared. Waleffe added that while the American liked to drink too much champagne, Böske Simon had temper tantrums but that she was the most aristocratique creature he had ever met; it was also rumored that this daughter of an Israelite doctor actually had noble blood coursing through her veins (Waleffe 447). 
Vasvári, Louise O. "Böske Simon, Miss Hungaria and Miss Europa (1929): Beauty Pageants and Packaging Gender, Race, and National Identity in Interwar Hungary." Hungarian Cultural Studies. e-Journal of the American Hungarian Educators Association, Volume 12 (2019) DOI: 10.5195/ahea.2019.360

8. A "4711" kölnivíz ötéves szerző́dést kínál neki azért, hogy ezalatt az idö alatt kizárólagos joggal ő használhassa fel reklámjain $\mathrm{Si}$ mon Böske fényképeit.

4. A Deauvilleben tartózkodó amerikai magyarok azonnal konzorciummá alakultak azzal a céllal, hogy Amerika minden magyarlakta városában Magyar Bált rendeznek, amelyen természetesen Simon Böskének személyesen fel kell lépnie.

5. Az egyik legnagyobb párizsi szalón igazgatónőjének akarja szerződtetni.

6. Zopott fürdóhely egész augusztusra meghivta öt és fejedelmi ellátáson kivül fényes ünnepségeket helvez neki kilátásba, amelyeknek jövedelméböl Miss Europa is részesedne.

Egyelöre ennyi is elég, hogy Keszthelynek tavaly meg névtelen szülöttje azon törje gyōnyörú fejecskéjét, kinek az ajánlatát tartsa a legkedvezöbbnek. Hiszen még alig pihente ki Deauville világ-

hírességeinek és multimilliárdosainak hódolatảt, máris egy megtisztelö és nem mindennapi meghívásnak kellett eleget tennie.

\section{A kapurtalai maharadzsa, aki azért utazott Párisból Deau- villebe, hogy szavazatát leadja rá, a választás után nagy es- télyt rendezett Simon Böske tiszteletére.}

$\mathrm{Az}$ estély szigorúan nyugateurópai formában folyt le és igy bizonyos mértékig talán csalódást is okozott Miss Europának, aki a kapurtalai maharadzsa pompás kis palo. tájában a hindu álomvilág csodáit várta. Persze a kapurtalai maharadzsa estélye csak egy platinaláncszem volt abban az ünneplési sorozatban, mely Simon Böske fèldiadalát követte. Es itt el kell ismerni, hogy Amerika pénzfejedelmei a választás után lojálisan elismerték Simon Böske lehelletszerủ szépségét. aminek egyik fényes bizonyitéka a Paramountnak már közölt szerzỏdési ajảnlata. S ez annál is többet mond, mert Deauville túlnyomóan nemzetközi elegáns társaságában, - tehát azok kö-

Foujita japán festômđớsz, outsider jelöltje

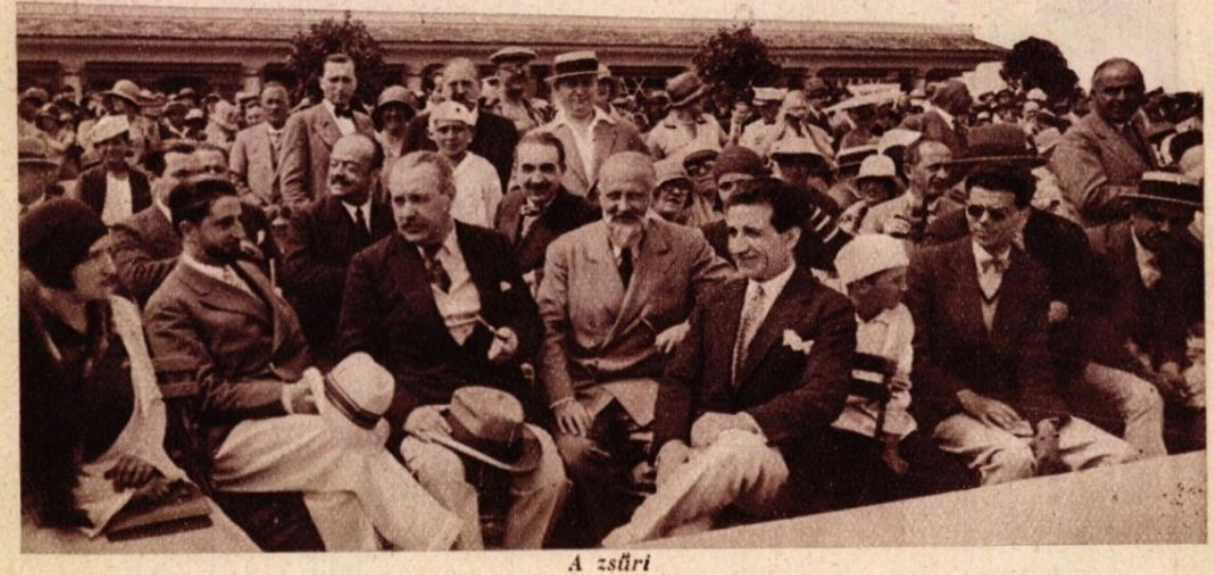

Balról-jobbra: Missis Sergent, Domergue festômđavész, Maurice de Waleffe, Van Dongen ês La Monaca olasz szobrisz 


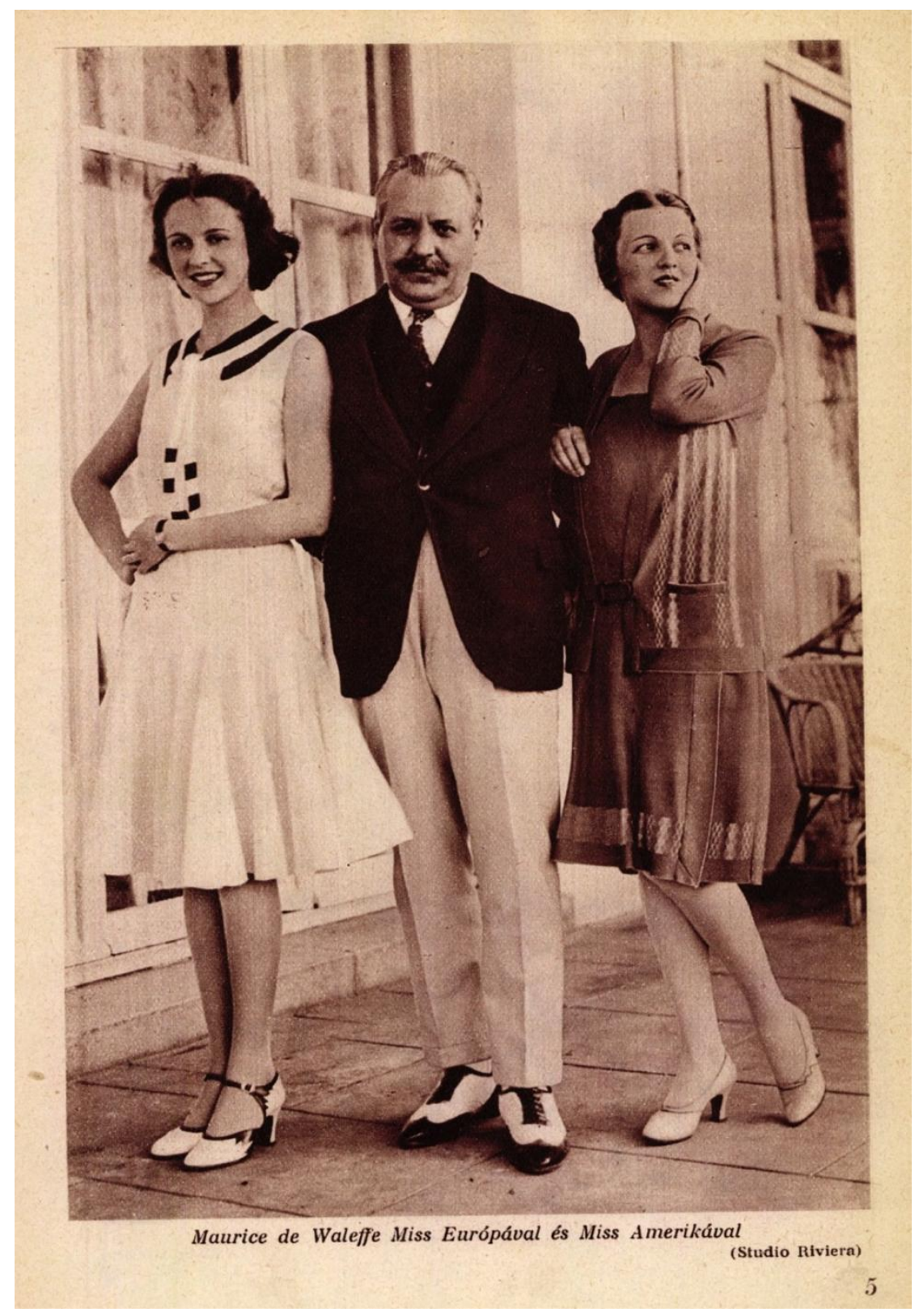

As for the alternative Galveston Miss Universe contest, on the advice of her father (who reputedly had always been hesitant to let her compete) Simon withdrew, claiming she was afraid of the long journey. It seems more likely that she was fearful of further public anti-Semitic insults. She might have also been scared off by the admonishment of the Galveston Roman Catholic Bishop Edward Byrne, who urged all contestants by letter to refrain from participating in the competition for the sake of their self-respect and claimed - not without reason - that the contest was merely a vulgar advertising stunt and they would be asked to parade while clad only in a bathing suit before a motley crowd who would ogle them like beautiful animals. At least one other pageant contestant, Miss Ireland, was also prevented from attending due to the agitation started in Irish Catholic newspapers about the supposed immorality of the contest (as cited in 
Webb 1929). The Miss Universe contest in Galveston was won by another Jewish contestant, Lisl Goldarbeiter, Miss Austria, who in the earlier Miss Europa contest had been the first runnerup to Simon. As we shall see below, her life, too, was to take tragic turns that were similar to Simon's life.

In the spring of 1929, Simon wrote a serialized autobiography composed in a gushingly girls tone for Szinházi élet. She begins by bragging that her mother had been raised as an úrilány and even learned horseback riding, just like the neighbor földbirtokos lányok ['daughters of landowners']. At the same time Simon remains silent regarding her father's humble origins, (understandably) the family's Jewish origins and the fact that she received an Orthodox education. Simon ends her story by saying that since she became famous, she has been asked everywhere about the "modern girl," whom she describes rather blandly as a girl who is livelier, quicker and more clever than girls used to be, not to mention that this type of woman can be beautiful both at home and at work. Yet in her closing words, Simon emphatically distances herself from the modern girl category by expressing no personal ambition beyond that of saying that although she has yet to fall in love, she looks forward to the time when she would be the wife of a suitable husband, a circumstance that would transform her happy experiences to no more than memories of her youth. Nevertheless, Simon did pose for some cosmetic advertisements, as can be seen in these two French illustrations, the first for a day cream to remove make-up residues and a night cream, the second for the world-famous 4711 cologne:
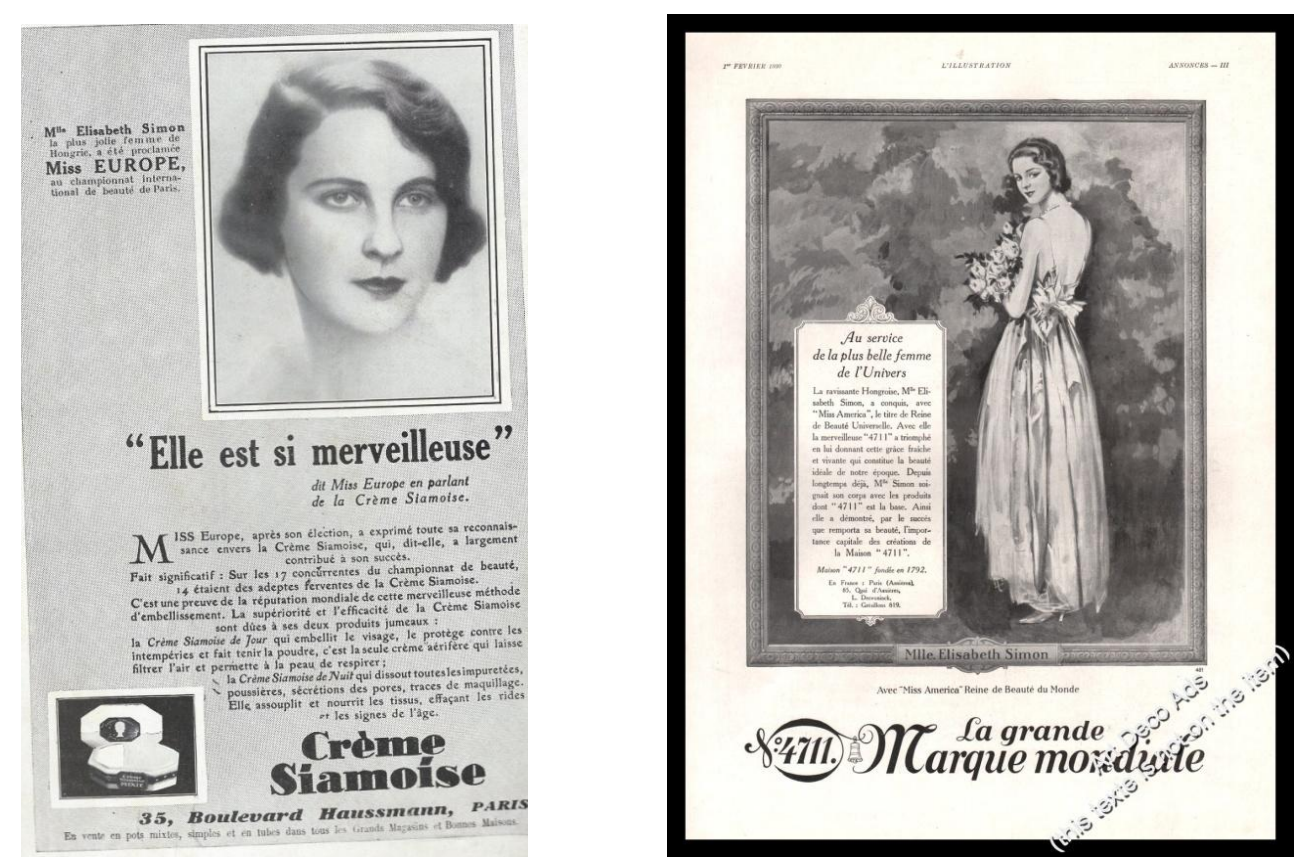

On December 22, 1929, just ten months after winning the Miss Europe title and six weeks after being introduced to him, Simon's wish to be nothing but a wife came true when she married Pál Brammer (1895-?), heir to the legendary textile emporium founded by his father, Ödön Brammer (? -1945). (In no account was it ever mentioned that Pál was actually Ödön's nephew, whom he had adopted at the age of two following the death of his brother, Henrik, the owner of a chocolate factory.) The couple married in a civil ceremony, with no religious 
ceremony following it (see the early newsreel (https://filmhiradokonline.hu/watch.php?id=9320). Bulvár magazine reported a minute description of the bride's outfit, including details of the fabric of her oversized, transparent georgette hat. As usual, her white skin was praised, while the fact that she wore no rouge or lipstick was also emphasized, just as several previous reports had claimed. ((http://www.huszadikszazad.hu/bulvar/simon-boske-es-brammer-pal-eskuvoje). After the wedding Szinházi élet (February, 1930) even reported information regarding the list of those who had sent congratulatory telegrams and another list of the wedding gifts. In the group photo below Simon's father is at extreme left, her mother behind her; the happy couple pose in the second photo before the departing on their honeymoon.
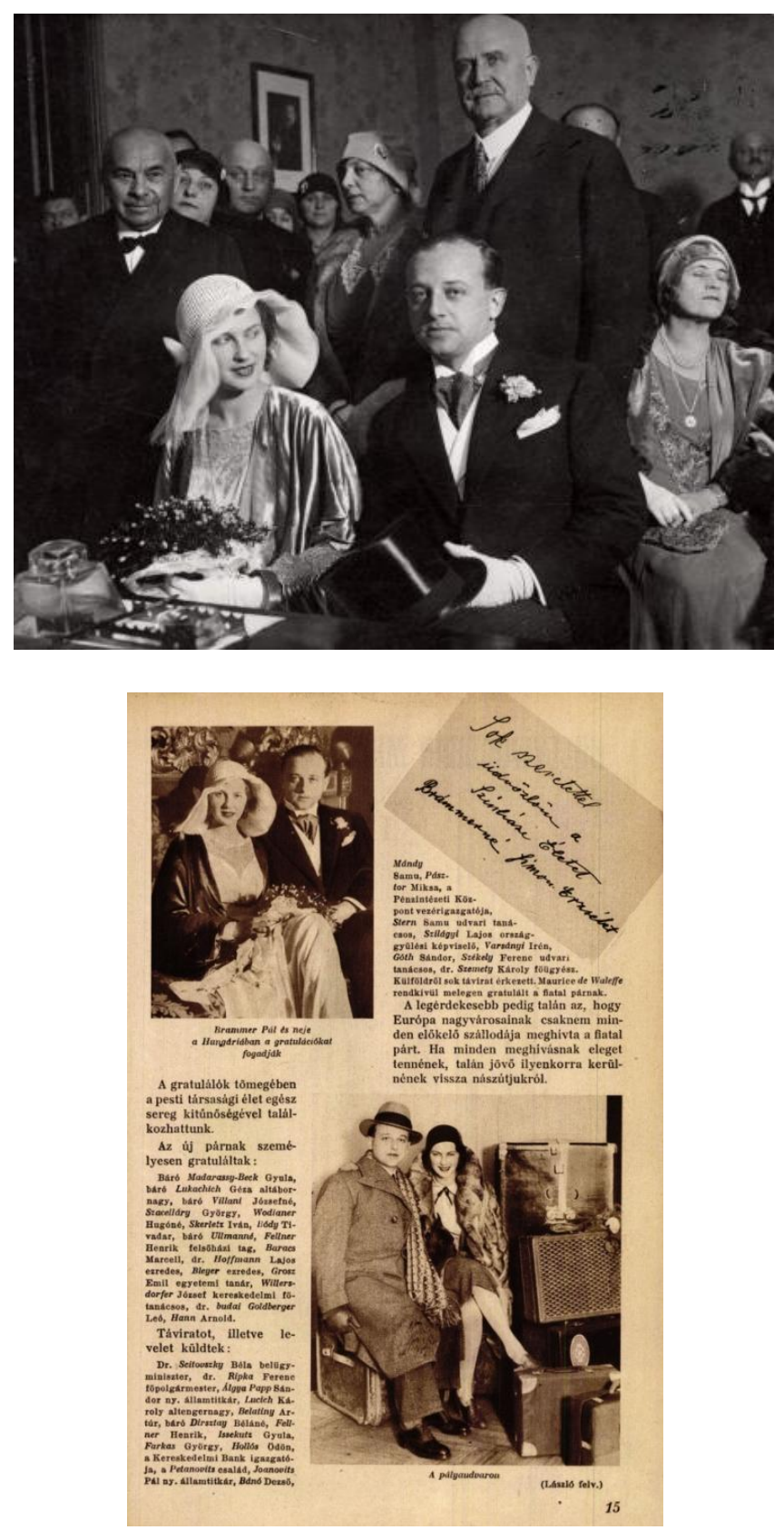
The magazine reports and the marriage itself were a kind of indirect advertising campaign for the Brammer textile business. Although from humble beginnings, Brammer père understood early on the spectacular development of consumer culture and specifically the new commerce of fashion. In imitation of Paris department stores, he had already opened in Budapest his first grandiose luxury palace of commerce in 1888 for the purpose of selling nöi és férfi divat kelme külonlegességek ['men's and women's fabric specialties']. Brammer advertised his store as the place to purchase luxury fabrics úrhölgyeknek vizit toilletekre ['for ladies' social wardrobes'] (http://budapest1kor.blogspot.com/2012/09/a-brammer-uzlet.html) and became known as the posztókirály ['king of broadcloth']. Brammer also became a textile tycoon by opening his own factory, where he could control the quality of his textiles, which-bearing their patriotic labels of Hungary's national colors of red, white and green - were exported to large department stores throughout Europe in the early part of the century. Brammer also understood the transformation of business concerns from production to consumption and the need to create the desire for products among potential consumers by establishing distinctive brand names, display techniques and other means of advertising (on the new consumer culture see further Bowlby 1985, Medvedev 2018). Here is an illustration of Brammer's first department store from an advertisement postcard in 1918:

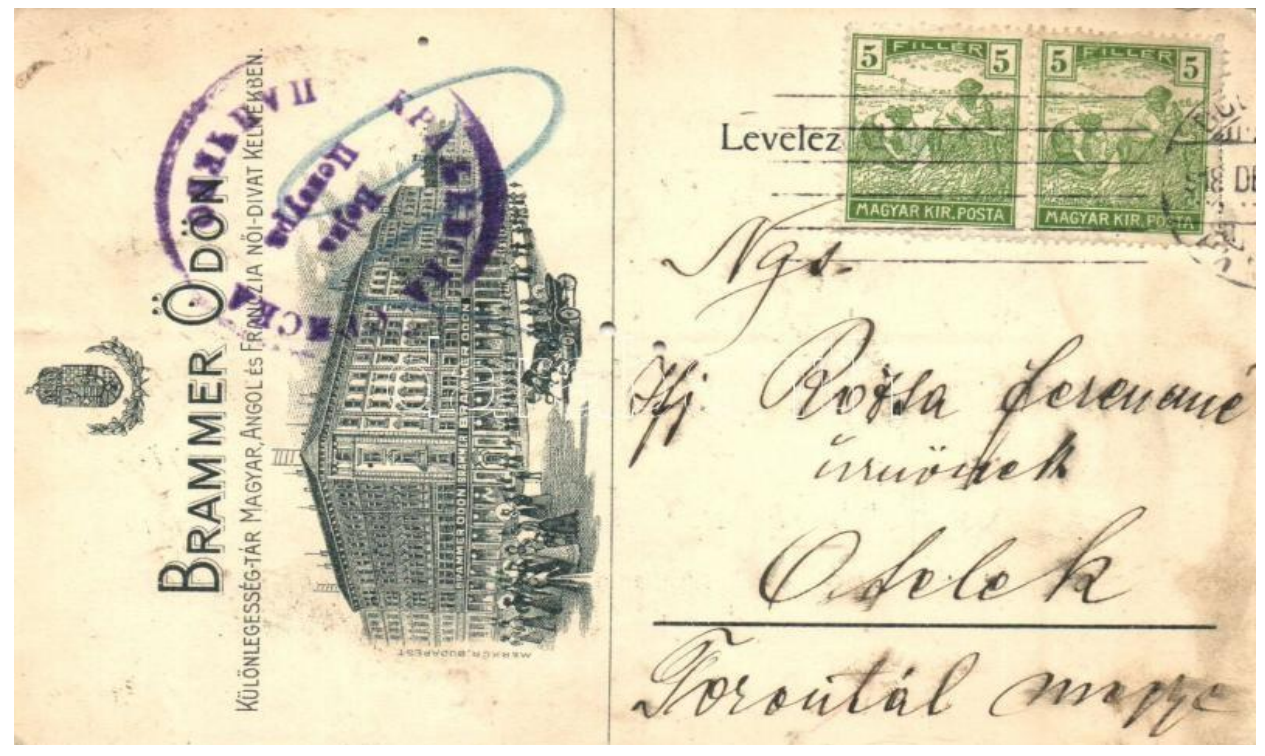

Although Brammer was virtually ruined during World War I, in 1924 he opened an elegant store at a new location found on Korona Herzeg utca (today 20 Petöfi Sándor Street and the corner of Régi Posta Street) which was mostly run by his son by the 1920s. The building has a grandiose exterior architecture and boasts one of the most beautiful Secessionist entrances in Budapest: 


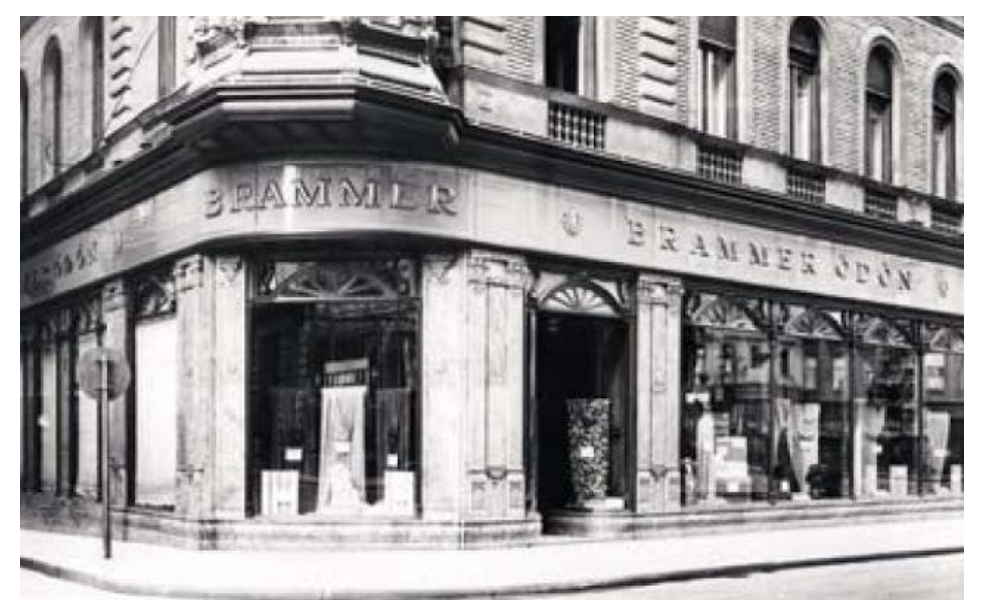

Similar to Germany, in Hungary it was Jewish entrepreneurs who founded most clothing, textile, and fashion houses; in popular culture, the world of retail therefore became a kind of cultural code for Jewishness. Patronizing such stores meant buying from Jews: within this reality, the responses of traditionalists to consumer culture as well as to the Jewish question became deeply interwoven (on Jewish fashion business, see further Wallach 2013: 114ff, Lerner 2015). The department store itself became emblematic of consumer culture and metropolitan modernity and simultaneously provoked both awe and admiration as well as fear and rejection. Anti-Semitic discourses pinpointed the rising power of Jewish-owned retail industry as a source of unease. Brammer, who understood the importance of display when constructing his showy stores as "secular temples of commerce," clearly saw the advertising advantages inherent to having his son marry a beauty queen. Unfortunately, the couple were so ill-suited that they not only divorced in 1935, but in April 1935 Brammer fils fought a rather ridiculous, mock duel by revolver against Dániel Jób (1880-1955), artistic director of the Vigszinház ['Comedy Theater'], over the alienation of the affections of Simon. Although neither opponent was hurt, both were fined. Twenty-nine years Simon's senior, Jób, pictured below, soon became her second husband.

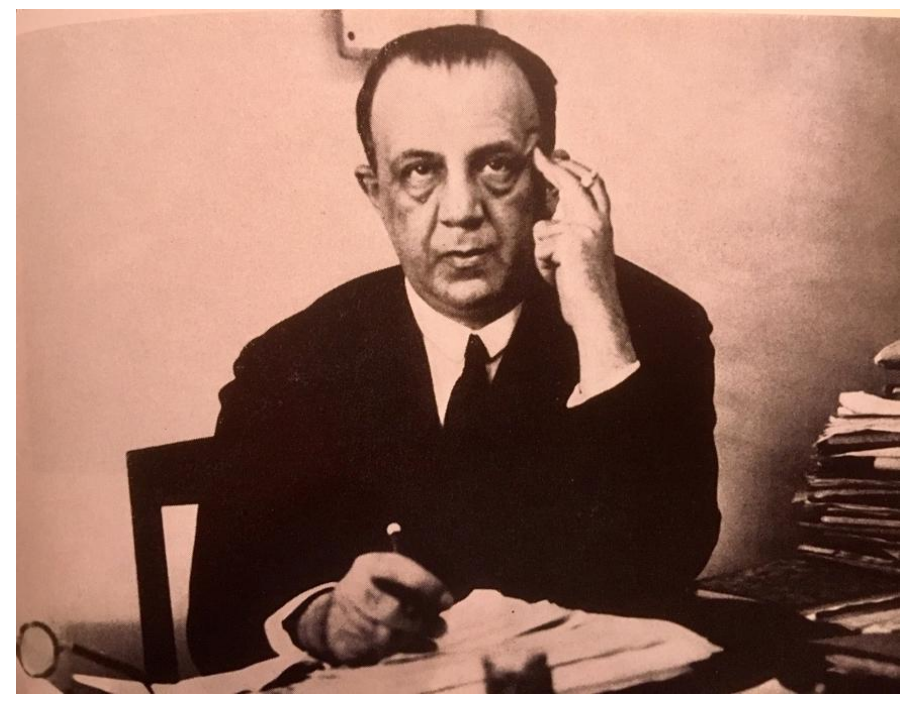


As a Jew, by 1939 Jób was no longer allowed to work at the Vigszinház, his place of employment since 1921. The couple survived the war by remaining hidden in 1944 in the cellar of the actor, Géza Berczy's villa. Simon, however, emerged from this tormented period both emotionally and physically shattered. Her parents numbered among the eight hundred-twentynine Jews deported from Keszthely, all but six of whom perished in Auschwitz. (On the history of Jews in Keszthely, which dates back to the eighteenth century, see Goldschmied and Szarka, 2005). Simon's ex-husband and family did not fare any better, as in 1940 Pál Brammer was imprisoned for three-and-a-half years for supposedly illegal price hikes; most of his family was deported in 1944. He himself survived and briefly tried to restart his business, but at the news of the nationalization of businesses, he left the country and his further fate remains unknown. Although the store was nationalized and for a time lost its sheen, as can be seen in the photo below from the sixties, it has been protected as a historical landmark since 1973. Today it figures on the list of UNESCO historical sites and its original structure is undergoing preservation. Since the late 2000s, the site has become an elegant Bizánc Boutique shoe store.

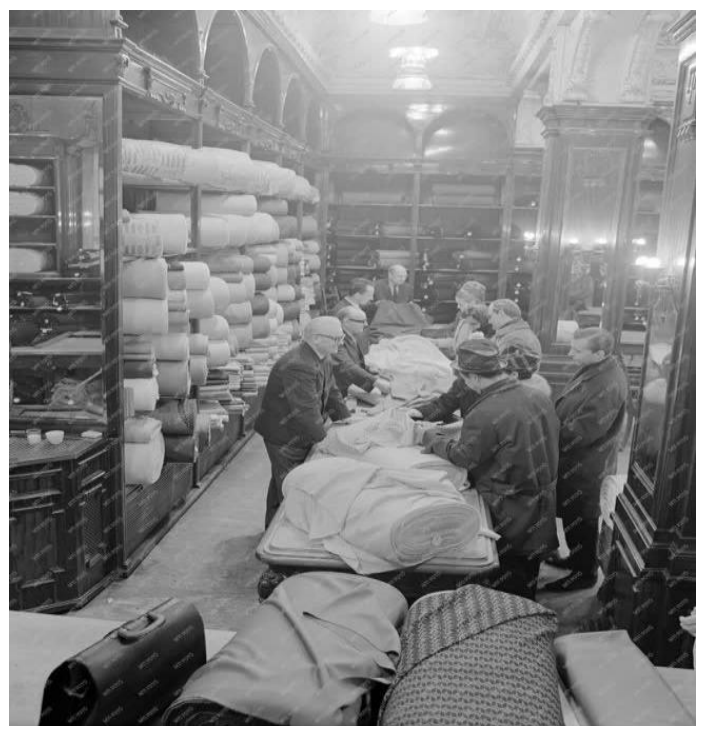

After the war, Simon and her husband were never able to reestablish their lives and lived in poverty until Jób's death. (See Szarka 2017: 131-132 for the poignant letter giving news of their and others' survival as well as those who did not and the difficulties of starting anew that Jób wrote in 1946 to Ferenc Molnár in New York.) Simon's health steadily deteriorated and from the time she was widowed in 1955 until her own death in 1970, she lived under the care of her brother, Imre Simon, and his family. Imre, who had been forced to study engineering in Germany due to the numerus clausus in Hungary, invented several very successful coffeemakers (the Atomic, Bambi, Electro Piccolo, etc.) and managed to run a successful private workshop and store even during the socialist period (on the coffeemakers see Vámos 2007).

A few, brief memorial articles appeared to mark the centennial of Böske Simon's birth in 2009; in 2017 Lajos Szarka, a historian from Keszthely, published Simon Böske naplója, which is a useful reference on Simon's life (cf. also Szarka 2010). The volume also includes selected quotes from contemporary authors who wrote about Simon (including Frigyes Karinthy and Sándor Márai), excerpts from how the newspapers belonging to various political factions reacted 
to a Jewish Hungarian Miss Europa and a rich trove of photographs that Szarka obtained directly from her family. There are, however, many photographs of Simon available in the issues of Szinházi élet that Szarka did not utilize. Additionaly, the title of Szarka's volume is highly misleading because there is in no sense of either a napló ['diary'] or an önéletrajz ['autobiography'] in Simon's "writing" that is reproduced in this volume, which actually constitutes the fluff piece Simon composed for Szinházi élet right after she won the Miss Europa competition. Sadly, the remainder of Simon's unfortunate life remains undocumented.

\section{Lisl [Elisabeth] Goldarbeiter, Miss Austria 1929, Miss Universe 1929 and Magda Demetrescu, Miss Romania 1929.}

Before proceeding to relate the relevance of Simon's status as beauty queen to the broader context of the interwar creation of the modern beauty contest and the concomitant construction of the concept of the "modern girl," mention must also be made of two other beauty queens of 1929. The experiences of Lisl Goldarbeiter (March 23 1909, Vienna - December 14,1997, Budapest) and Magda Demetrescu shed further light on the contests of that year, as well as upon the surrounding anti-Semitic reactions. As was already mentioned above, as Miss Austria 1929 and the first runner-up in the Miss Europa pageant, Goldarbeiter is in a sense the historical counterpart to Simon. Only one month younger, Lisl Goldarbeiter, whose Hungarian nickname was Liska, was actually the daughter of the Hungarian Jew, Izso Goldarbeiter, who was born in 1877 in Szeged. Goldarbeiter later emigrated to Vienna, where he eventually opened a modest textile store. Although Lisl Goldarbeiter's mother was not Jewish, the family lived in the Jewish district of Leopoldstadt in very modest circumstances. Unlike Simon, Goldarbeiter apparently attended a commercial middle school and worked in her father's store.

In every country that participated in the beauty pageants, a certain newspaper took on the task of advertising and managing the competition. While in Budapest it was Szinházi élet that sponsored Simon and published anodyne articles concerning her reign, in Austria it was primarily the Neues Wiener Tagblatt that sponsored Goldarbeiter. Interestingly, while Simon presented herself in her self-description in modern terms (at least as far as bragging about being a great tennis player and sportswoman is concerned) Goldarbeiter declared that she does not partake in sports and is only moderately interested in dancing. Their differing self-presentation is telling, as participation in sports was coded as a symbol of both modernity and elegant upbringing, while middle class women were encouraged to engage only in limited activity. At the same time, for both women it was important to take every opportunity to emphasize the lie that they did not use cosmetics. For example, Goldarbeiter declared in one interview for the Neues Wiener Tagblatt (Jan. 30, 1929) that when she went out she only used a bit of rice powder; she used no other cosmetics beyond this and washed her face with regular tap water. After Goldarbeiter's victory, one of the headlines in the same paper found it important to repeat the claim that she won without using powder or lipstick. From today's standpoint, it seems strange why one would want to disown the use of toilet soap just as much as that of lipstick. Beginning in the 1920s, soap ads promoted global beauty brands like Lux and Palmolive as a skin cosmetic and warned against the use of harsh ordinary soaps while also featuring star endorsements. That is, soap was marketed not only as a hygiene product, but also as a product akin to a skin cream at a time when tensions between the ideas of so-called "natural" and "unnatural" beauty swamped magazines (Hackney 2010: 130; Burr 2013). For example, in one issue of Szinházi élet (1928, 19.1, Dec. 30-Jan. 5) the first page features a titillating ad for Savoly 


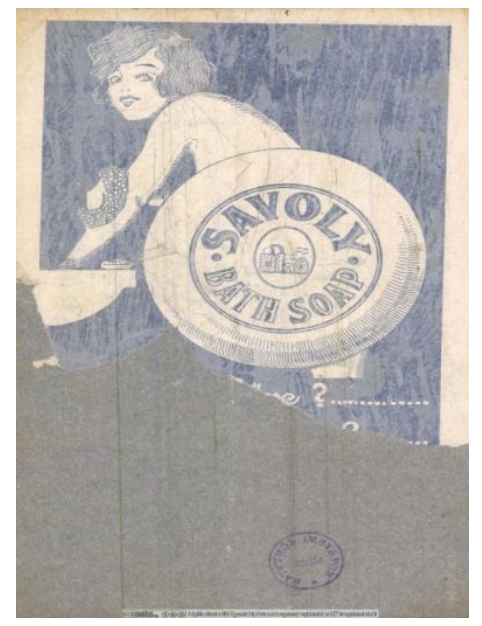

Bath Soap that includes a drawing of a sexy nude girl bathing, her hair in a modern bob while only a round bar of soap placed in the picture's foreground blocks her body from view. Goldarbeiter's disclaimer of using such soaps is a declaration of her wholesome innocence and rejection of cosmopolitanism and modernity.

Although Goldarbeiter received the same letter as Simon from the Bishop in Galveston warning her not to go to Galveston, she still went, accompanied by mother. Her trip was not sponsored by the Galveston pageant but by the Neues Wiener Extrablatt, a left-wing, liberal paper that realized it could increase its circulation by writing about a beauty queen and therefore offered to pay for Goldarbeiter and her mother's passage if she sent regular reports. Since she was not up to the task of writing, her mother paid a reporter traveling with the group for his reports, based upon which Goldarbeiter cribbed a few passages. Her reporting was anodyne, to say the least, but what was of interest was how little in America was to her liking. She especially criticized the terrible food and how every course was always served, as she wrote, with ice water (Tenczer 2000: 63). In Galveston Goldarbeiter became the first non-American to win the Miss Universe title in a competition consisting of over twenty-five American girls and eight Europeans, plus a Miss Brazilia and a Miss Cuba. She received two hundred dollars and a platinum watch from Bulova in compensation. In Galveston Goldarbeiter declared in her acceptance speech (delivered in German) that her greatest ambition was only to marry, have a home and be back in her beloved Vienna. She was offered a film contract by the famous King Vidor, one of the jury members, as well as a theater contract for $\$ 15,000$, an opportunity which she did not accept supposedly because she did not want to appear in a bathing suit. The bathing suit competition was an important part of the Galveston contest, as can be seen in this British Pathé newsreel of the seven contestant:

https://www.britishpathe.com/video/VLVAAC5CZ60NOLOAX5XB2T8K3QDIE-USA-MISSUNIVERSE-CONTESTANTS/query/wildcard . Below see photos of Goldarbeiter as Miss Austria, a cover photo of her in the Viennese illustrated weekly, Wiener Bilder, her crowning as Miss Universe in Galveston, and a photo of her with her mother, who was voted the most attractive mother of a contestant.
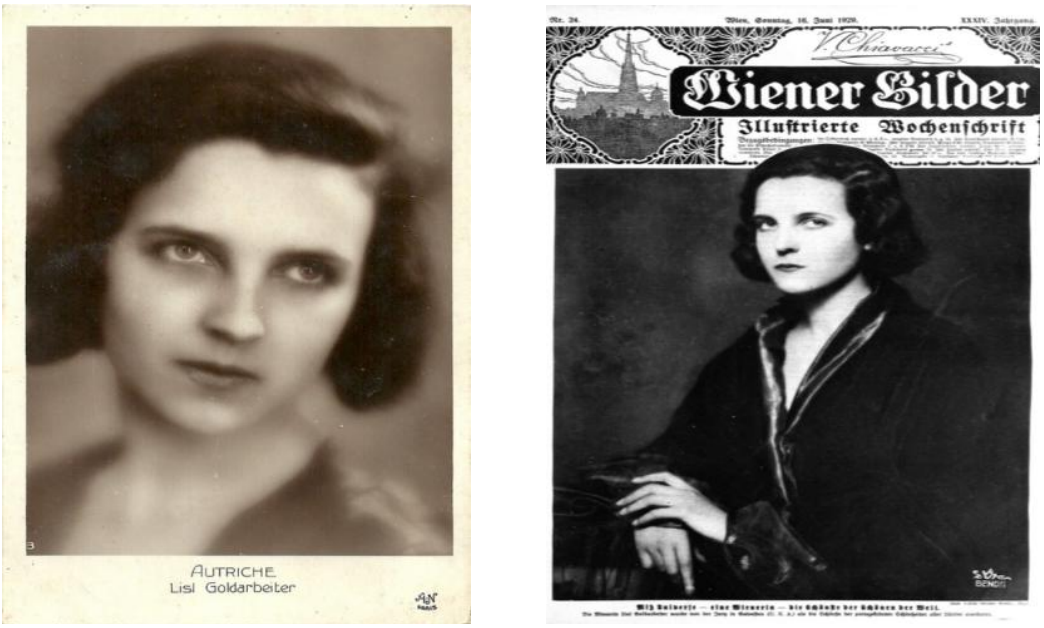

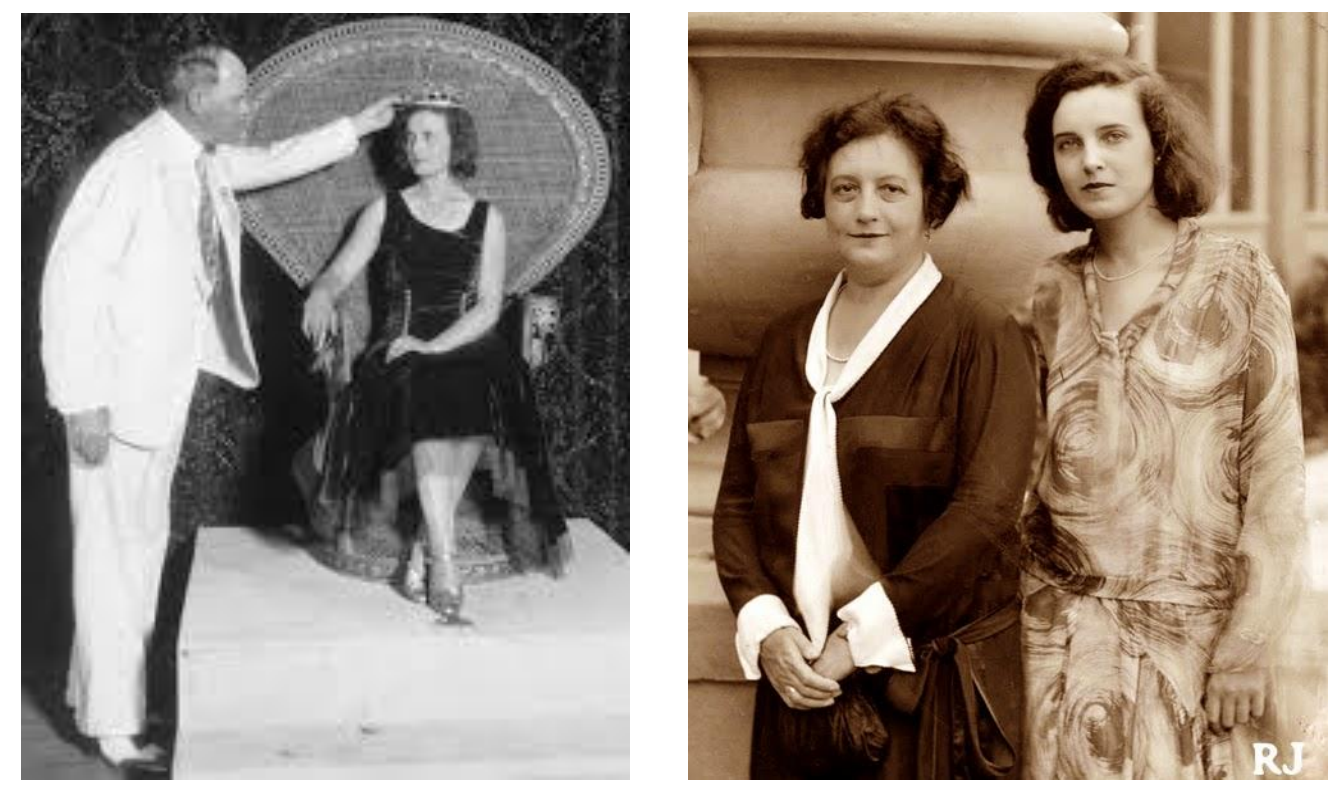

Unlike Simon, during her reign Goldarbeiter traveled extensively throughout Europe and visited Romania, where she met Miss Romania, the seventeen-year-old Magda Demetrescu (1922 - ??), who had competed unsuccessfully against her in the Miss Universe contest. Little is known about Demetrescu's background other than the information that she was an orphan raised by an aunt (Gavrilă 2013, Catchy 2014). It should be noted that during the interwar period there were sometimes competing beauty contests on both the national and international level, as we have seen above in the case of the competing Miss Universe pageants in Dauville and in Galveston. Demetrescu was the Miss Romania 1929, whose contest was organized by the Realitatea ilustrată, while in the Miss Europe contest Simon competed against Marioara Ganesco (Janescu), Miss Romania 1928, below, who entered that contest in 1929 under the sponsorship of a competing illustrated magazine, Ilustraiunea Română.

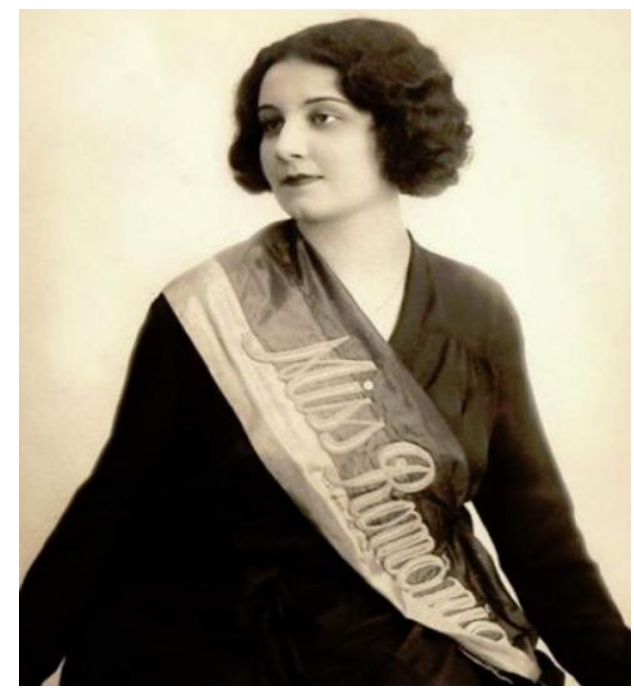


Upon her arrival at the Bucharest railroad station, Goldarbeiter (just as Simon had experienced in Budapest) was jeered by a crowd, who subjected her to anti-Semitic slurs, including shouts of "make her eat pork." The crowd also shouted that she was too thin in comparison to their more curvaceous national candidate. Miss Romania had to escape with Simon and seek refuge in the Bucharest Cathedral, but the mob demanded that Goldarbeiter be ejected, shouting that as a Jew she had no right to seek shelter there; finally, a large force of police intervened (New York Times, Aug. 30, 1929; Sept. 15, 1929; in the latter article the pork insult was omitted; compare Wallach 2013: 136). Although the attacks against Goldarbeiter were primarily anti-Semitic and nationalistic, they were also based on local aesthetic criteria: the crowd found her to be too skinny at a time when the commodification of slenderness as a beauty ideal, promoted both by the Hollywood star cult and various sports and health movements in the twenties, had not by any means obtain broad social approval (on the new cult of slenderness, see Thoms 2013). See below Lisl Goldarbeiter as Miss Universe in Galveston, with Miss Romania third on her right.

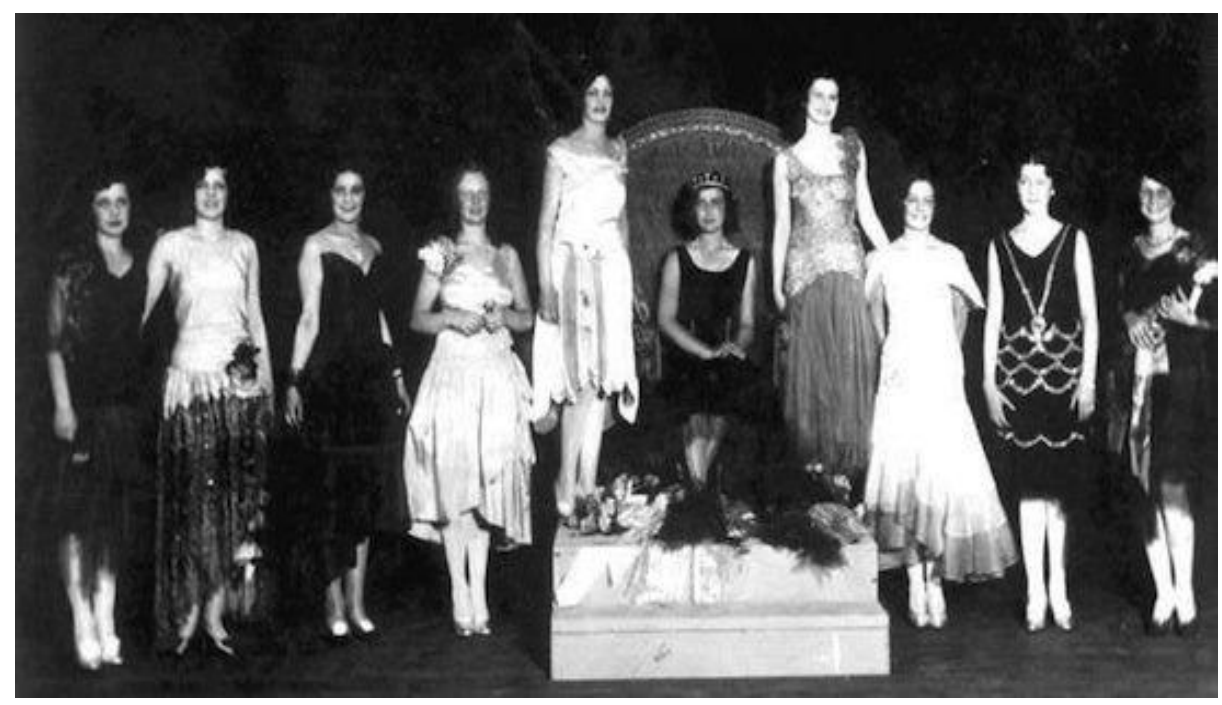

In its June 15, 1929 issue, the Szeged newspaper, Délmagyarország ['Southern Hungary'], reported that Miss Universe's close relatives, her father's sister and cousins, the Tänzer family, lived in Szeged. In the article Goldarbeiter is described in terms very similar to those used to describe Simon in other newspapers, such as a szerény, finom úrilány ['modest, refined young lady of good family'], whom others had to push to submit her photo to the competition

(https://www.delmagyar.hu/delmagyarchiv/egy_evszazados_szerelem_tortenete/2426988/). During Goldarbeiter's reign her first cousin from Szeged, Mór "Marci” Tänzer (1909-2003), who had been in Vienna since 1926 as an engineering student, was living with Lisl and her parents. An amateur filmmaker, Marci recorded Goldarbeiter's successes in the pageants, all the 
while nursing his unrequited love for her, when he knew he could not succeed against all her rich suitors. Indeed, soon after her victory, Goldarbeiter, just like Simon, entered into a first, disastrous marriage with one Fritz Spielmann, the playboy son of a rich silk necktie manufacturer. Speilmann fled Vienna after the Anschluss and ended up in New York. ${ }^{\dagger}$ Directly after Kristalnacht, Goldarbeiter fled with her parents for the perceived greater safety of Szeged, from which her father (along with the Tänzer family) was deported in 1944 and all perished. Goldarbeiter survived in hiding with her mother and remained in Szeged after the war. Goldarbeiter's cousin, who had nursed his passion for her since their youth and had continually filmed and photographed her, returned after six years of being, first, as a munkaszolgálatos ['labor service conscript in the Hungarian army'] and then as a prisoner-of-war. In 1949 the two married and settled in Budapest, and Marci continued to take photos of Goldarbeiter throughout their fifty years together, until her death in 1996. In 2000, at the age of ninety-one, he published a small volume, Szerelmem, Lisl ['My Love, Lisl'], with his photographs of her and a very edited account of her life, in which, for example, he makes no mention of any anti-Semitic attacks against her during her reign, nor even of her marital woes in her first marriage, although vestiges of the latter appear in the films (Tenczer 2000; note that spelling change in Tänzer's last name).

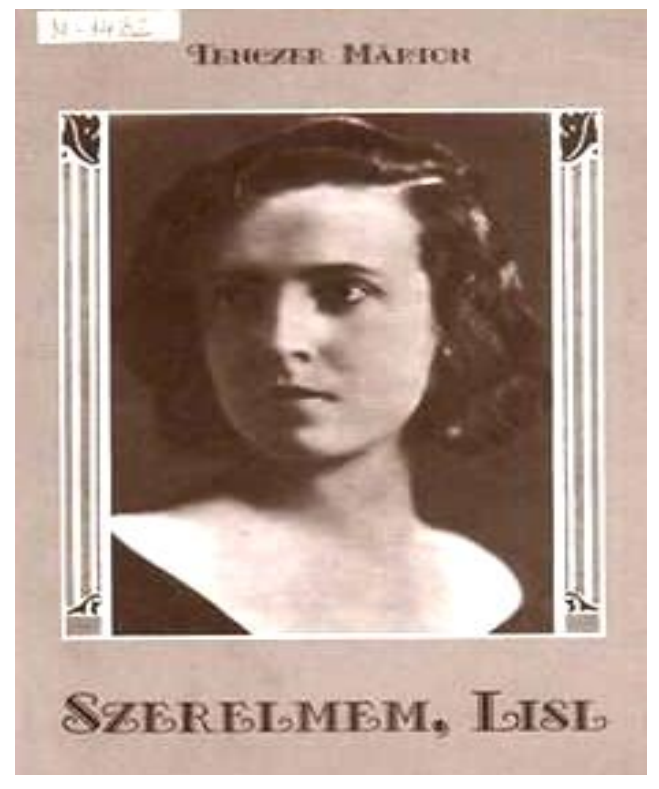

\footnotetext{
$\dagger$ Thanks to a memoir by another Viennese refugee, Edith Kurzweil, I was able to discover that Spielman was known as "Kravatten Spielmann" in the Viennese emigré circle that congregated at the famous Éclair pastry shop in New York City, the hangout of Central European Jewish refugees (Kurzwel 2007). If I cannot help adding this seemingly mundane detail it is in part because Goldarbeiter's cousin and later husband claims all trace of Spielmann were lost in the US, when he was actually an active part of the Austrian refugee community. I also mention it because when I arrived as a refugee child in the US a decade-and-a-half later, to me the same Éclair still represented a vestige of the world I had lost.
} 
Using Tänzer's film, Péter Forgács made a beautiful documentary entitled Lisl Goldarbeiter - a Szépség útja, in 2005. The English version was issued as Miss Universe $1929-$ Lisl Goldarbeiter: A Queen in Wien (https://www.youtube.com/watch?v=L4ruHhNOj-k and https://vimeo.com/51056779) (on the film, see Portuges 2011). Below see a composite ad from Forgács's film, using photos made by Tänzer of Goldarbeiter and also including some of him at various ages.

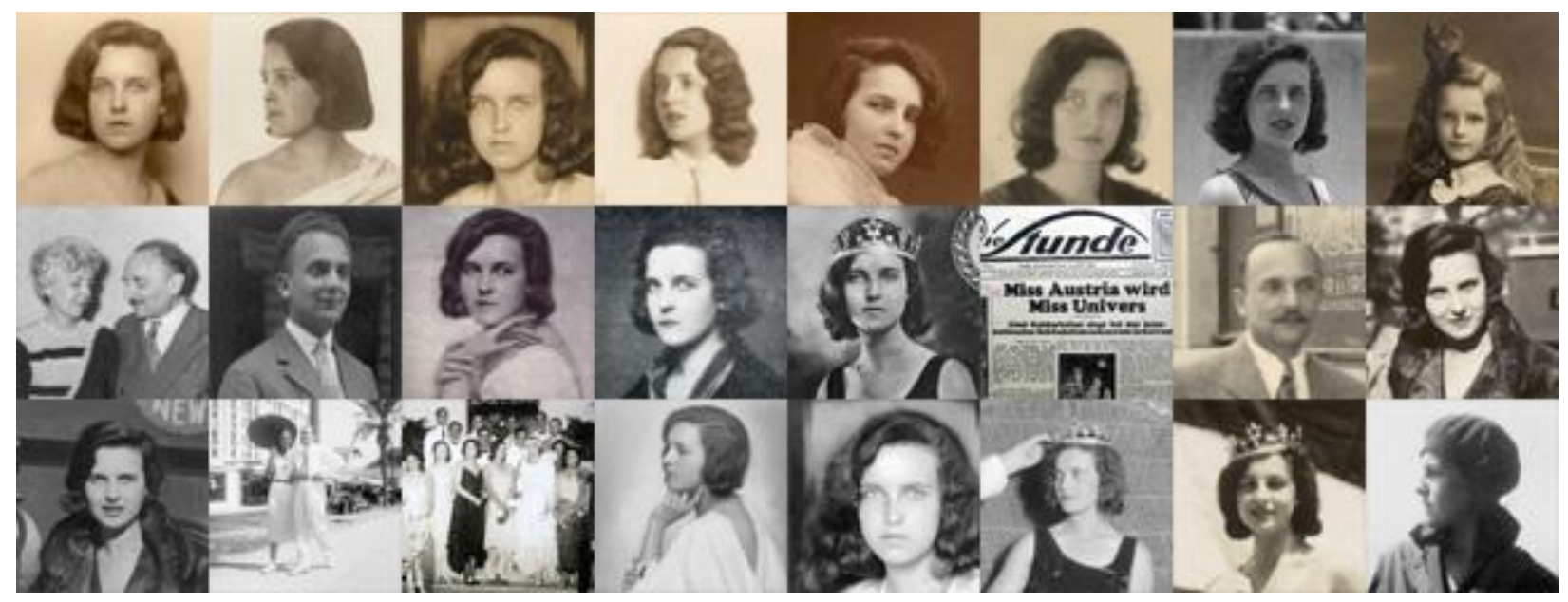

Beauty Pageants as Cultural Sites for Packaging Gender, Race, and National Identity:
From Miss America and Miss France to Miss Magyarország/Miss Hungária

As I stated at the beginning, because Böske Simon is a forgotten name today, I felt it necessary to begin this study with an overview of her life, including mention of some of her family and important contemporaries as a means of briefly locating their lives in the tumultuous interwar period. This study therefore concentrates on the era when Hungary was characterized by the dominant ideologies of the creation of a post-Trianon national identity and increasing antiSemitism, then extends through the period of persecution Hungarian Jews particularly faced between 1944 and 1945. In this section I aim to place Simon's role as Hungarian beauty queen within the broader focus of this study: to examine from a gender perspective the rapid international development of beauty pageants as a central arena for performing beauty in the 1920s, intertwined with the creation of the concept of the "modern girl," both fueled by the rapidly emerging global consumer culture and supported by the press and the new media, especially illustrated magazines and newsreels. I will examine the symbolic space allotted to the beauty queen, who could be packaged as the transnational Modern Girl, yet at the same time also be utilized to reinforce conservative notions of gender roles in national identity politics and thereby stand for the purity of the national $f a j$ ['race'].

It is no coincidence that the first Miss Hungaria was chosen in 1929, as the late 1920s marked the proliferation of beauty pageants, which developed in collaboration with rapidly expanding consumerism as an early example of cultural globalization (on beauty and connection of consumerism see further, Ganeva 2013: 111). Let us briefly review the origin of these modern beauty contests as a popular institution for the culturally-sanctioned public display of women and their bodies. It is P. T. Barnum, the American showman, who is generally credited with initiating 
the first American beauty contest in 1854 . However, such contests remained tame, clothed affairs until in the spread of fashion modeling in the 1920s, which became a glamorous, albeit barely respectable career choice for women. Fashion modeling, in other words, offered a prototype for these contests (on the rise of modeling in the twenties see Tetorka 2010). Named after the sawdust display dummies they replaced in couturier salons, the new couture mannequinperformers would silently parade in the costumes presented during elaborately staged fashion shows, not unlike the parades held in beauty contests (as can be seen in this 1920 Pathé newsreel, which even features one woman modeling underwear:

https://www.britishpathe.com/video/VLVAEC1CHH1JUVY43O1VICS8LDP24-FSHIONFASHION-SHOW-AT-OLYMPIA/query/wildcard). In the modern consumer economy in the early twentieth century, when the production of desire became central to the distribution of goods, these living, but silent fashion models became the most emblematic icons of glamorized femininity and male desire (as perhaps they still are today). Through the medium of their bodies, these mannequins were meant to produce desire in the consumer located in the salon, as well as via print advertisements. The display of the female body served to commodify forms of sexualized looking in the consumer, a process that was merely to be carried to the next step in beauty contests (see further, Conor 2004: 11, Brown 2014: 33). In fact, as of 1925 the Jewishfounded Gerson department store in Berlin actually ran a kind of quasi beauty pageant in the form of an upscale fashion show that bore elements of a beauty pageant for the purpose of choosing the most graceful model to be crowned as the Modekönigin ['Fashion Queen']. The second queen was the sixteen-year-old Hilde Zimmerman and Gerson model, seen here dressed in a crown and traditional royal vestments while wearing a bathing suit (Ganeva 2009: 128-130, Fig. 7.3):

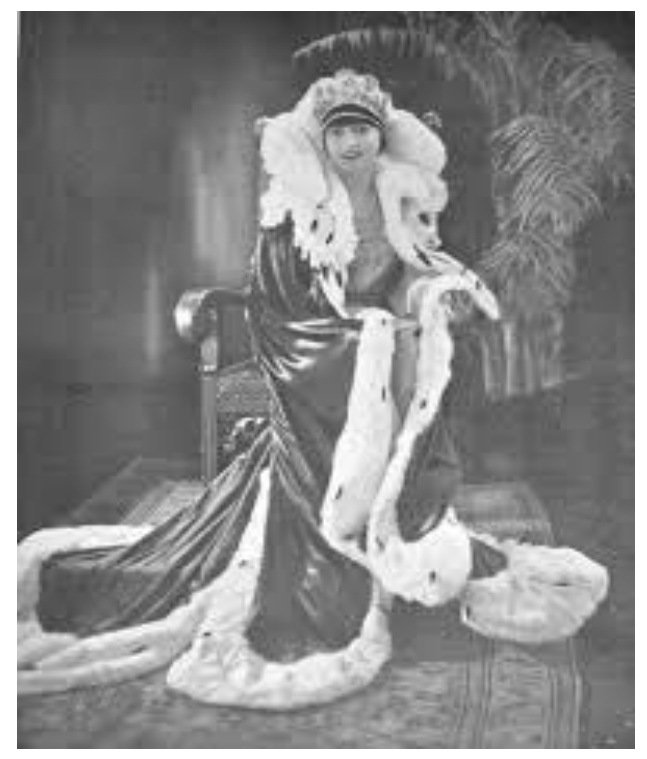

Concomitant with the live display of silent mannequins was the new visual culture created by fashion photography, in which art and consumer culture often intersected, a field in which Jews, and, interestingly, Jewish women, were disproportionally overrepresented. Photography promoted dazzling changes as mass-produced images of women as sexual symbols proved to attract customers via the new mass media, thereby promoting new ways of seeing and 
new ideals of beauty. As of the 1920s, many popular publications started featuring photos of beautiful women in order to stimulate sales, a technique made possible by the rapid development of photography and printing techniques (on the importance of the new technique of photography, see further Ganeva 2003, Sylvester 2008, Roemer 2013: 100).

It was in 1921 that one H. Conrad Eckholm, owner of the Monticello Hotel in Atlantic City, New Jersey, hit upon the scheme of a potentially profitable publicity stunt by devising a beauty contest with a bathing suit competition as its centerpiece, as a way to display female bodies outside of the confines of Vaudeville revues. Eckholm borrowed the promotional ideas from the risqué bathing beauties who usually appeared frolicking in groups that were featured in Mack Sennett silent films (https://silentology.wordpress.com/2015/08/24/splashes-of-fun-andbeauty-sennetts-famous-bathing-beauties/ ). In a European setting, see also the large group of identical Berlin bathing beauties line dancing in Luna Park in 1929:

https://www.britishpathe.com/video/VLVA28BKM13ENZJ0A55UYOL167RBP-GERMANYBERLIN-BATHING-BEAUTIES-IN-SWIMMING-POOL-AT-LUNA-PARK/query/wildcard As Angela J. Latham (1995; 2000) discusses in her aptly titled article, "Packaging Woman: The Concurrent Rise of Beauty Pageants, Public Bathing and Other Performances of Female 'Nudity," the public display of women wearing bathing suits, yet who were not entertainers formed the main appeal of beauty contests, precisely at a time when one of the most hotly debated and (literally) policed boundaries of women's pubic behavior was that of appropriate standards of swimwear. This was true even though the bathing suits permitted in 1921 and the women on display, as seen below, were hardly virtually "nude," or even attractive by the standards held merely a few years later, when Simon and Goldarbeiter competed in modernlooking suits in 1929, as we have seen above (on bathing suits in American beauty pageants see Watson et al 2004; Hamlin 2006).

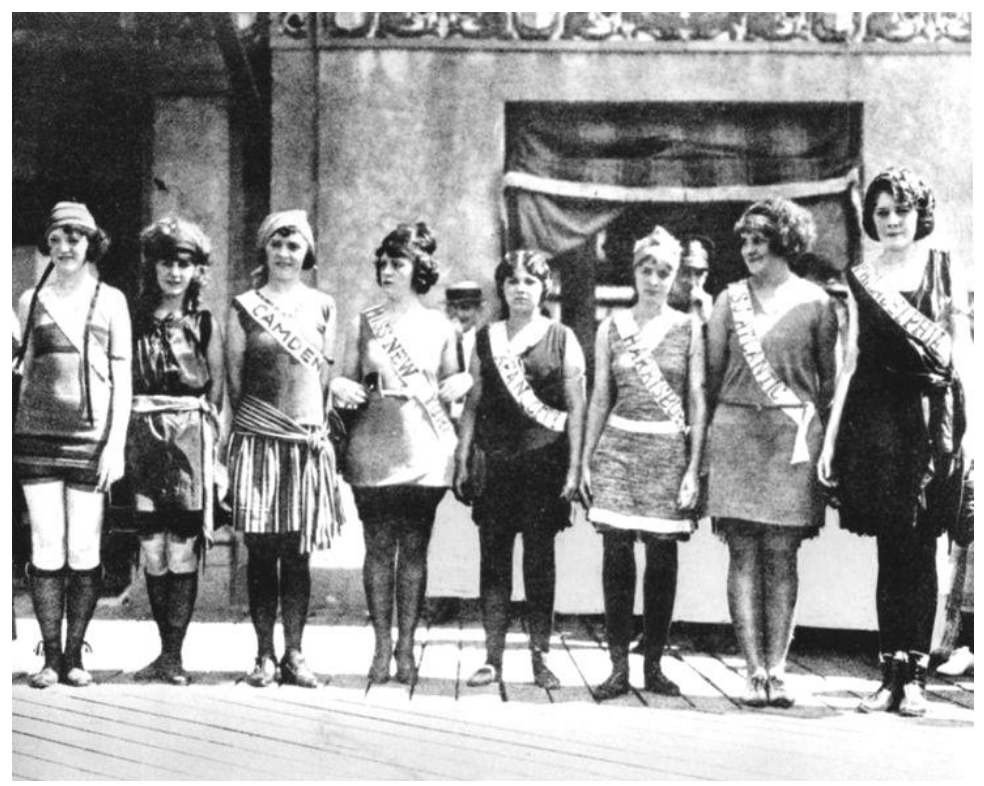

The winner of the first Atlantic City Miss America pageant in 1921 was Ellen Gorwan, a fifteen-year-old schoolgirl, who was dressed as the Statue of Liberty draped in an enormous American flag in her coronation photo. 


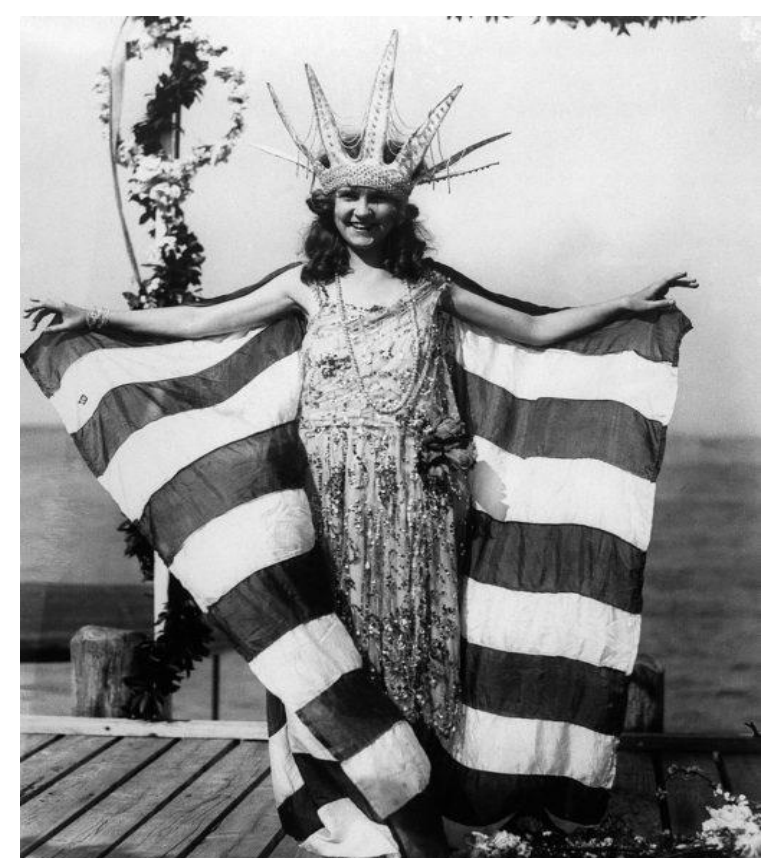

The deep seriousness of this national masquerade becomes evident in the newspaper accounts that marketed this teenage girl as the prototype of the true American girl, fit for motherhood and homemaking, upon whom the hope of the country's future rested. In the uneasy post-World-War I period in the United States, the political threat against capitalism was represented by Bolshevism while the threat to patriarchy and gender unease was represented by the passage of the Nineteenth Amendment in 1920 that granted women's suffrage, and by the general increased visibility of the new women (from suffragettes to flappers) beyond the private sphere. In such a period of rapid political change, the almost childlike, demure, flag-draped Miss America was needed to represent a nostalgic representation of a safer era when women were kept in their "proper place." By consistently selecting contestants such as Ellen Gorwan, who least resembled a "flapper" or "new woman," the pageants promoted a standardized and retrograde ideal of womanhood. The press and public alike meanwhile lauded these first Miss Americas for neither having bobbed hair, wearing make-up nor smoking cigarettes. The contests in the U.S. continued for a few years, with ever-revised rules, such as the addition of an evening gown competition, an element that disappeared in 1927. Due to the Great Depression, the evening gown competition was not to be revived until 1933, and even then in much subdued form until after World War II. (It was only in 1945, in the first pageant held after the war, that the first and to date only Jewish Miss America. Bess Myerson, was elected.)

In her groundbreaking book, The Most Beautiful Girl in the World: Beauty Pageants and National Identity (1999: 2-7, 59) Sarah Banet-Weiser dissects pageants as complex cultural sites in which ideas of race, gender, and nationalism are negotiated and contested on the public stage. She studies pageants as a civic ritual and mass-mediated spectacle that embodies a variety of nationalist expressions that are firmly embedded within commodity culture, wherein a given group can tell stories to themselves about themselves, providing an avenue for voicing underlying conflicts and tensions affecting the community. Pageants are also a highly visible 
performance of gender, wherein (as we have seen above in the case of mannequins) the disciplinary practices and cultural scripts that construct women as feminine are palpably on display; contestants subsequently come to represent the female body as a national body. The traditional female icons used as symbolic representations of the nation and bearers of cultural values (from the aforementioned Statue of Liberty or Delacroix's Lady Liberty, to Marianne, Britannia, Helvetia, Polonia, Pocahantas, La Malinche, and, of course, Hungaria, among many others) can also be considered from this viewpoint. During the interwar period Hungary was often personified as csonka ['wounded or maimed'] (see Weaver 2006, whose book features a flaming Hungaria on its cover). Below, see first a stamp with Hungaria riding to battle, in which

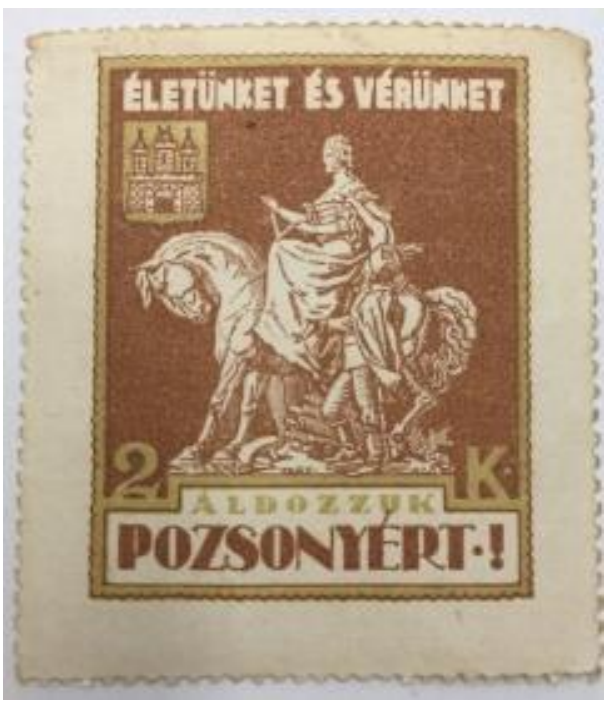
the caption states, "Let us sacrificy our life and our blood for Pozsony." The second illustrates Hungaria showing a flaming map of Hungary with outlines of greater Hungary and csonka Hungary inside. The third is a greeting card wishing the recipient a double resurecction, a Christian one for Easter and also the resurrection of Greater Hungary: Feltámadunk! Boldog husvéti ünnepeket! Magyar feltámadást! ['We

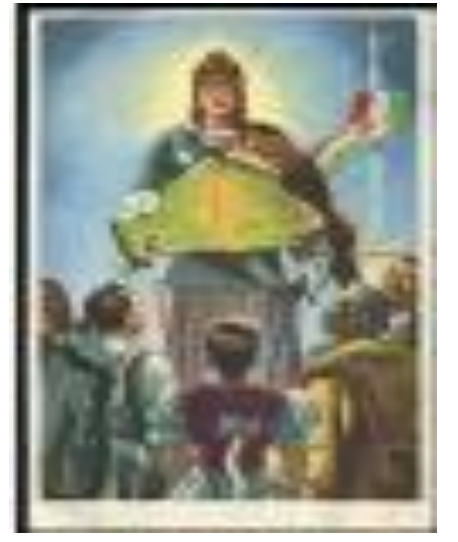
shall be resurrected! Happy Easter! To the resurrection of Hungary!']

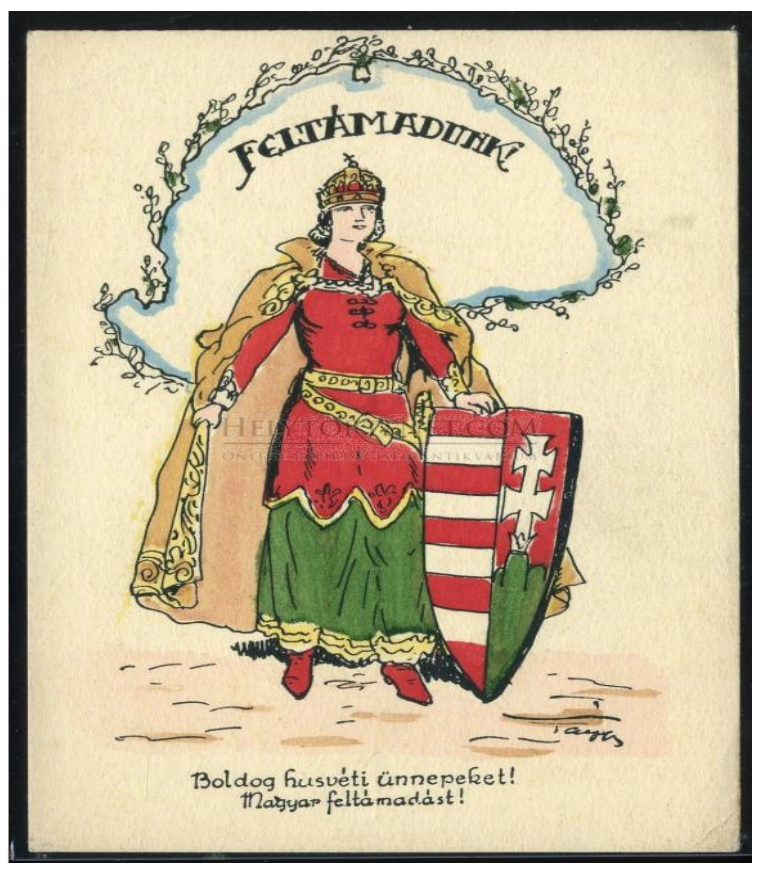


Although Banet-Weiser concentrates on the US pageants in her work, she cogently argues that similar notions of the gendered construction of national identity are repeatedly played out in pageants across the world. An edited collection by Colleen Ballerion Cohen et al., Beauty Queens on the Global Stage: Gender, Contests, and Power (1995), provides precisely these examples, with chapters examining beauty pageants across the globe, from Andalusia to Tibet, and Moscow to Guatemala, while always illustrating how pageants demonstrate the relation of women to nation as well as relations between states and nations. See also Huma Ahmed-Ghosh's discussion in her article, "Writing the Nation on the Beauty Queen's Body: Implications for a Hindu Nation" (2003: 205), in which she describes current Miss Indias who are as nationally fêted in a manner similar to sports figures and given glamorous coverage on the front page of national dailies as a symbol of national pride, thereby serving to show the world that India has arrived on the global stage as a modern country, even though the contest are simultaneously condemned by conservative ideology. We can briefly return here to the example of Böske Simon, who upon her return home seventy years earlier, was both celebrated and maligned while the importance of her victory for Hungary was compared (at least in the Jewish press of the time) to the glory achieved for the country by the 1928 Olympic medal winner in fencing, Attila Petschauer (1904-1943), whom we know, with ironic hindsight, was tortured and killed in a Hungarian army labor camp in Ukraine in 1943.

Having briefly reviewed the socio-political context within which Miss America pageants evolved during the1920s, let us now focus on how European and, specifically, Hungarian beauty pageants began. In 1920 in France, Maurice de Waleffe (1874-1946), the Belgian-born French journalist who was already mentioned in Section I and pictured with the two Miss Universe winners, initiated the "La plus belle femme de France," contest. In one chapter of his memoir, "La defense de la beauté" ['The Defense of Beauty'], he describes in some detail all the contests he organized, his obsessions with desirable versus non-desirable forms of interracial marriage and well as his rather peculiar sexual tastes, such as his belief that the most beautiful girls in the world were the barely adolescent Chinese "taxi-girls" weighing between twenty-five and thirty kilos whom he met in Singapore clubs. It is unpleasant to consider that a man who expressed these kinds of sexual and political views was the power behind European beauty contests for over a decade.

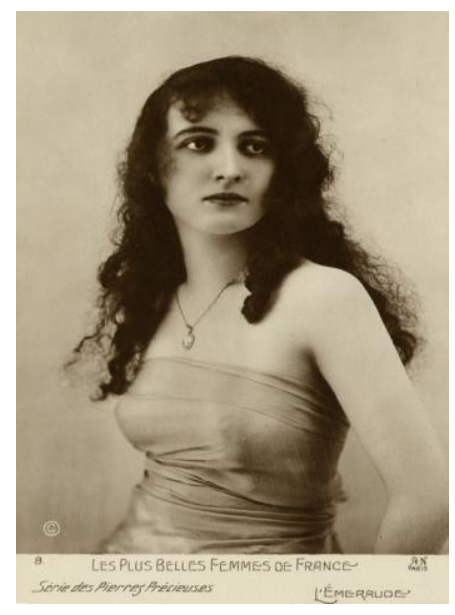

De Waleffe claimed that one thousand-seven hundred girls submitted their photos to the first French contest that he organized. The first winner was Agnès Souret (1902-1928), a seventeen-yearold French girl from Bayonne who had been born of a Basque mother and Breton father and displayed a very "ethnic" look. With her dark curly hair and enormous dark eyes, Souret was the exact antithesis of the Modern Girl-look contestants would employ only a few years later, although some of the six other finalists in this contest already had bobbed hair. Although the poor girl refused to go to Hollywood, she agreed to appear in the Folies-Bergère and died of appendicitis only a few years later, during a tournée in Argentina, which she had accepted only to pay for her villa located in her birthplace. 


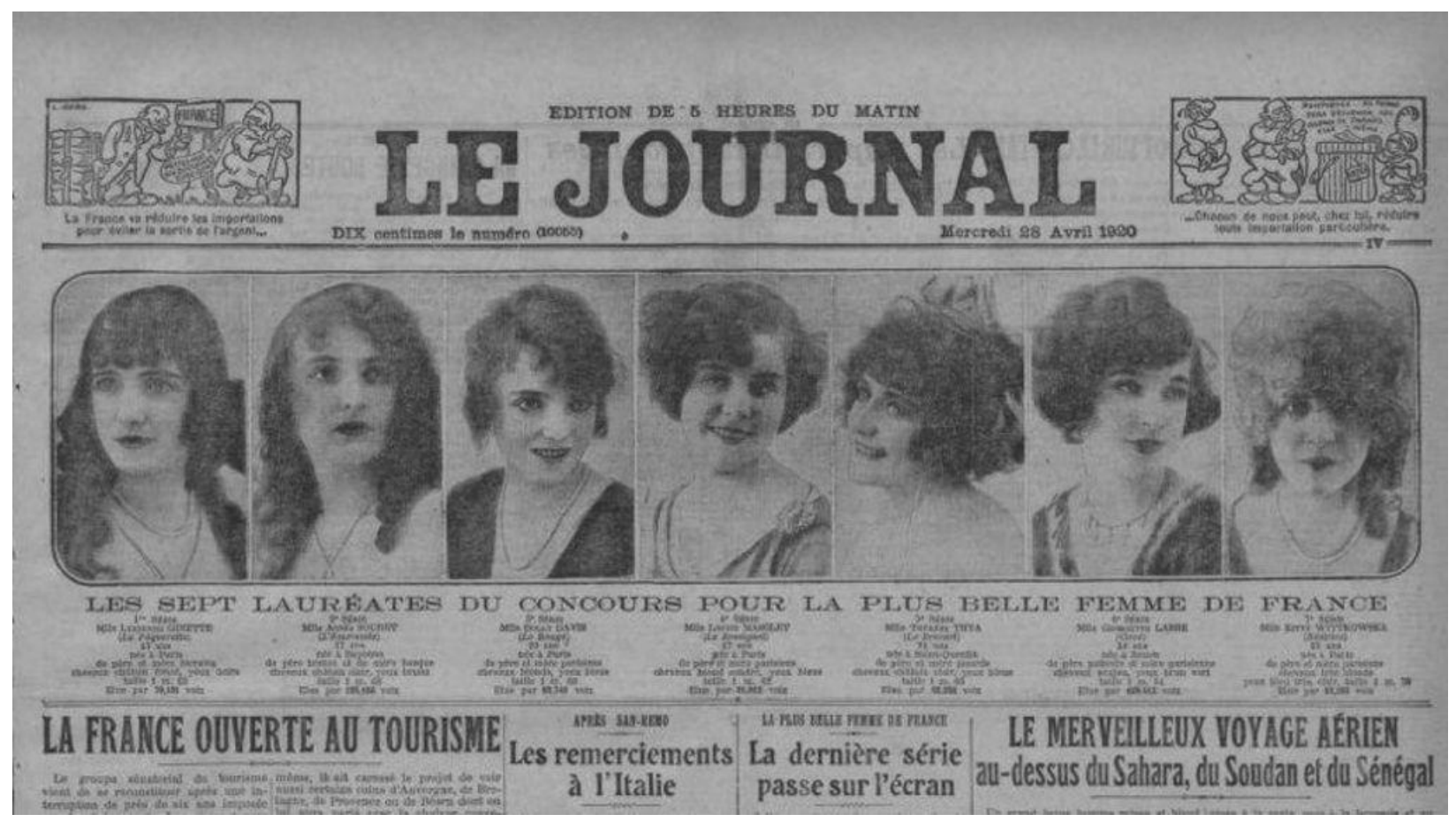

After being suspended for five years, the French contest returned in 1927 with the title of Miss France (on the French contest, see further Velmet 2014). It was also in 1927 that the first Miss Germania was chosen, joining the emerging global beauty pageant craze, although in 1933 the Nazis put a rapid end to what they deemed as a decadent practice in which contestants did not represent true national beauty.

By 1929, de Waleffe had taken the contest to the international stage by founding Miss Europe followed by Miss France d'Outre-Mer for the sake of the French colonies. He wanted to valorize provincial beauty, whose rural roots he claimed would guarantee health, fertility and tradition. At the same time, he was also in a sense somewhat "liberal" in his attempt to combine traditional notions of femininity with some more progressive ideas. For example, he allowed French women born to foreign parents to compete, claiming that the mixture of different blood would vitalize a race depleted by civilization and in need of repopulation after the Great War. De Waleffe's ideas regarding the reproductive role of women reflected racial nationalism or pronatalist, bio-political movement in the aftermath of the Great War, the proponents of whom sought to make reproduction a matter of compelling national interest, a discourse that often intersected with nineteen-twenties scientistic racist discourse. In interwar Hungary, for example, as we already saw in the example of MANSZ and the Turul group, the racial discourse employed by right-wing rhetoric intersected with racial anti-Semitism and the "woman question," in which women's roles were defined as biological reproduction of the pure "Magyar race" that had suffered decline primarily due to miscegenation, but also due to "civilization" and secularization (on scientistic racist views on reproduction in Hungary see further Kund 2016: 216; and, more broadly, in Central and Southeast Europe, see Turda and Wedling 2007).

De Waleffe made use of modern advertising techniques, the rise of the popular press and the expansion of modern communication media to spread his message more widely. His pageants started as an attempt to establish role models for a French modernity that was anchored in 
provincial tradition in contrast to degenerative urban modernity which, along with the Great War, had disturbed proper gender roles. However, the pageants gradually and increasingly became a vehicle for the liberal Modern Girl ideal. In 1929, when de Waleffe initiated the first Miss Europe competition, he contacted Sándor Incze, the editor of Szinházi élet, to promote the pageant in Hungary. Incze began the campaign by publishing a pretentious article written by de Waleffe in defense of the recently begun beauty pageants. In this article, de Waleffe rejects the charges of immorality that surrounded these events while emphasizing that they represent the appreciation of what he terms as the precious and fragile and sadly short-lived female beauty that a beautiful woman represents, otherwise fated to fade away in the shadows. Continuing in the same pompous vein, de Waleffe asserts that just as archeologists are praised for unearthing ancient marbles or bronzes, he unearths living beauty and Venuses who bring brilliance to the whole world with their beauty.

Like de Waleffe, Sándor Incze also made use of the new media and especially of the new mass affordability of cameras, which transformed the medium of the photograph and allowed for less costly and complicated mass production in the popular press. Incze (1889-1996), who was Mór Stein until 1908, understood early on that this new technology made picture magazines commercially desirable as a new form of visual storytelling (see Hardt 1989 for further details on new picture magazines). Incze first established a theater periodical in his native Kolozsvár, but initially struggled to do the same in Budapest, where there were another six entertainment magazines. Eventually, Incze's illustrated weekly became very popular, although after World War I, when a large part of the readership was displaced beyond the nation's shrunken borders, like all other publishers he, too, had to scramble to rebuild his circulation. Incze always had to be on the lookout for stories to fill up his illustrated weekly that would boost his circulation and the promotion of the Miss Hungaria competition was just such an opportunity.

In Szinházi elet (1928.19.1., dec 30-jan 5) Incze announced that the first Miss Magyarország pageant would be held on January 6 and Maurice de Waleffe had invited twenty countries to take part in the Miss Europe competition that was planned to follow, but Budapest was the only city where de Waleffe would appear in person as a judge.

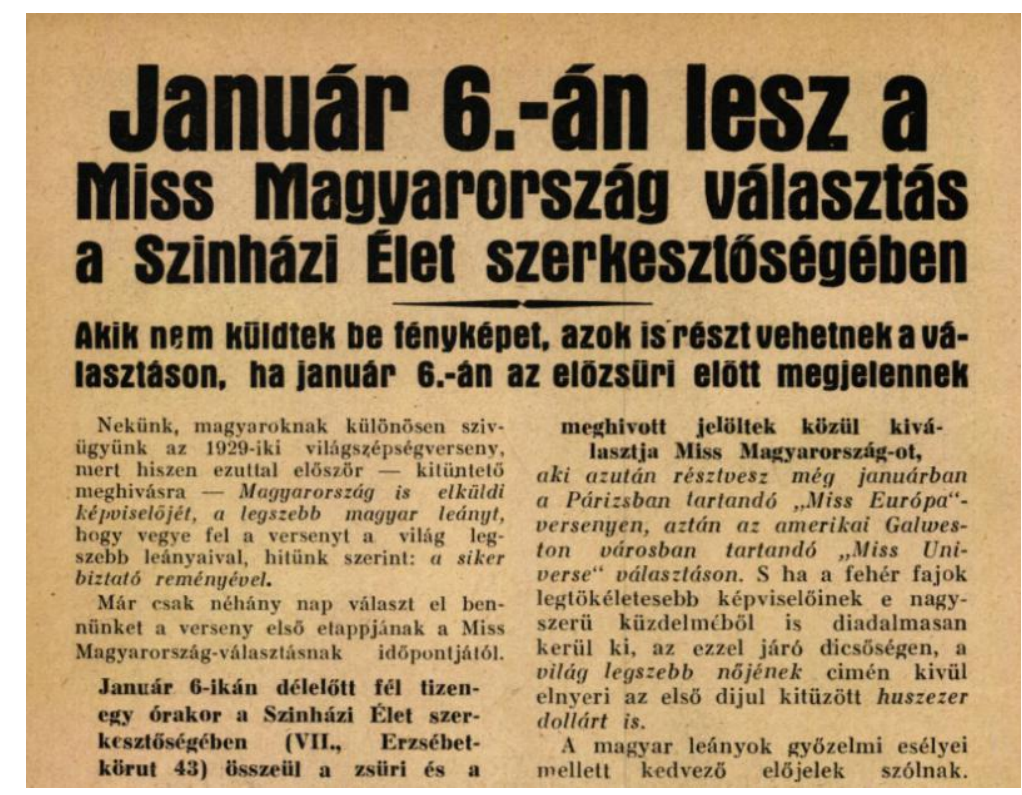


For the first pageant, jury members included esteemed writers like Jenő Heltai (who cofounded Szinházi élet with Incze and wrote in every issue of the magazine), Menyhért Lengyel, Gyula Pékár, and Lajos Zilahi; the list also included titled personages, such as Count Géza Zichy and Count Tivadar Zichy, as well as two very interesting women, the author and feminist, Countess Teleki Sandorné (Szikra) (1864-1937) and the famous actress Emilia Márkus (1860-1944). As of yet, this first contest contained no bathing suit component and all contestants could appear in any outfit of their choosing. The magazine promised to send the winner and her mother by first-class on the Orient Express and also provide them with four nights in a Paris hotel; if the same contestant were to win the Miss Europa contest, then she would receive firstclass accommodations while traveling to Galveston. For some reason, Incze claimed then as well as in the subsequent year that the prize for Miss Universe would be $\$ 20,000$, although the actual prize (won later that year by Lisl Goldarbeiter) was $\$ 2,000$. In the last three issues of 1928 that were published before the contest took place, Incze featured a couple hundred photos of contestants (almost all headshots) that were interspersed throughout the magazine. Most of the girls are ordinary, but what they virtually all have in common is their bobbed hair. Many additional photos of girls who were both Jewish and gentile and came from all parts of Hungary appeared in the first issue of the new year. (For good measure, this issue also carried photos of a gyermek szépségverseny ['a children's beauty contest'].) Below is an example of the first page of the many pages of photos published of the contestants:

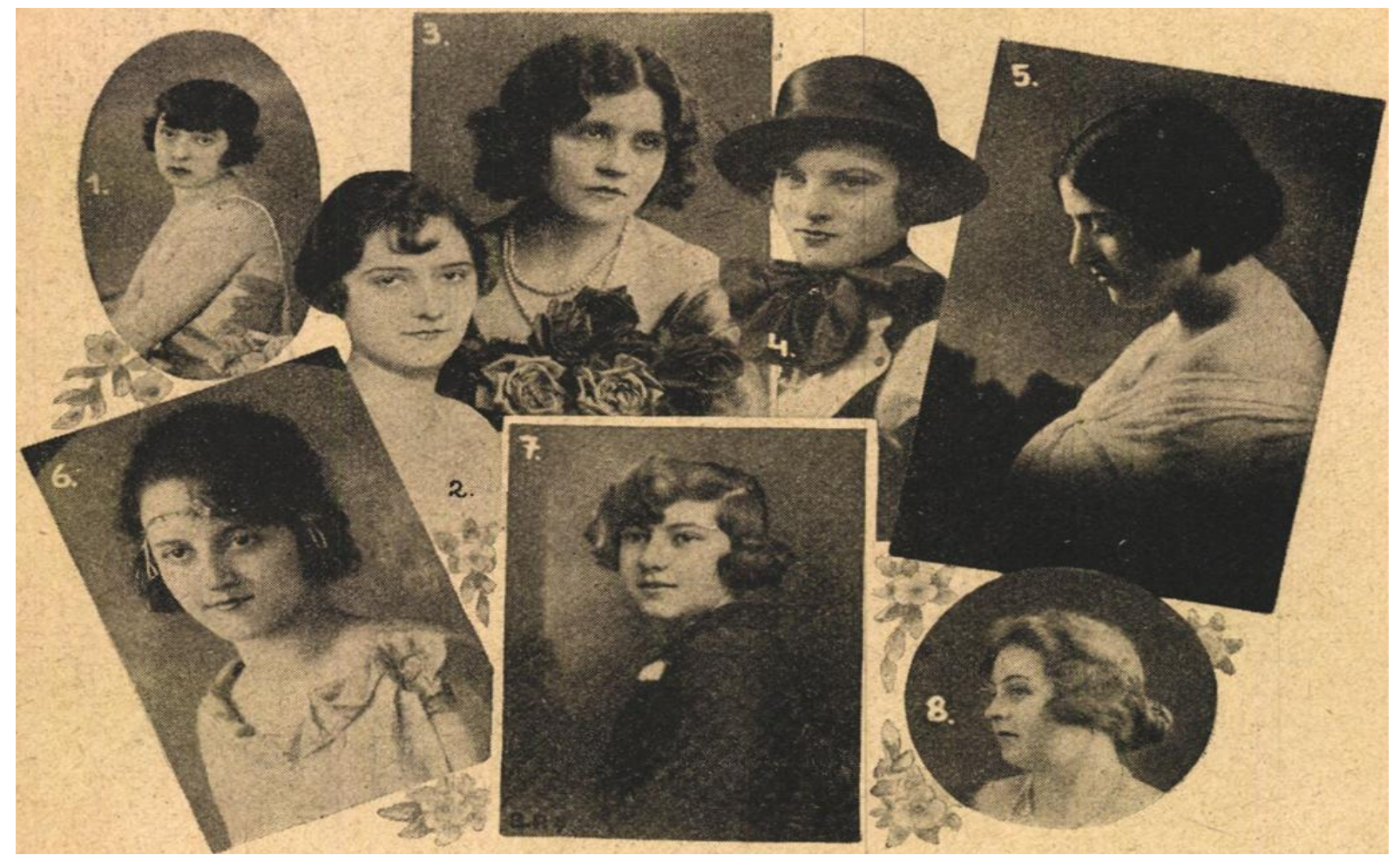


Held in the editorial offices of Szinházi élet, the first Miss Hungaria beauty contest took place on January 9, 1929. Aas promised in the announcement, the head of the committee was none other than Maurice de Waleffe himself. The finalists can be seen in the illustration below, with Simon the third from the left:

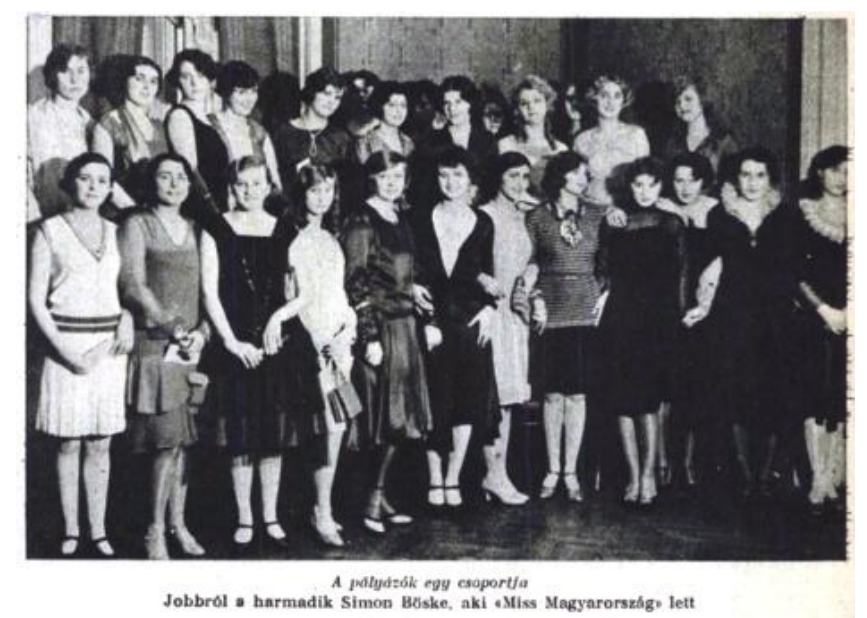

Only one point behind Simon, a seventeen-year-old typist called Daisy Lefkovitz was not only the runner-up but also bore a conspicuously Jewish name. Accompanied by her mother and Simon Incze, the winner, Simon, went on to the Miss Europa pageant, held at the Paris Opera House on February 7, 2019 for participants from seventeen countries. An Albert Besnard of the Académie Française headed the imposing list of judges, who included painters and sculptors. Nevertheless, the event was lacking in organization, with the girls complaining that they were made to wait for some eight hours in an overly heated and probably too crowded room since two of them fainted (as reported by Webb 1929).

Simon's victory was such a success for Hungary as well as Incze that he gleefully repeated the whole process in issues at the end of 1929, once again promising that de Waleffe would officiate. The preparations for the 1930 Miss Hungaria contest attracted even more contestants who sent in their photos, and once again Incze published seemingly innumerable photos of girls in several issues. Although the girls as a group were no more glamorous than the previous year, many of the photos were now taken professionally and signed by the artists. Some were no longer merely headshots, but full body poses (Szinházi élet, Dec 29-Jan 4, 1929). A number were signed by Angelo (born as Pinkász Funk, later Pál Funk [1894-1974]), who was an important personage in the history of Szinházi élet. Just three years apart in age, he and Incze had met in the army during World War I. Incze realized that the talented, but as yet unknown photographer could help him build up Szinházy élet with many more photos instead of the drawings Incze was still using. The two formed a lasting partnership and the many photos Angelo took of stars for the magazine, as well as his art photos, made him famous and sought after not only in Hungary but also in Europe (see further Pentek, 2018, and the film on Angelo by Sólyom 2004). It is not clear if some of the pageant hopefuls sought out Angelo to take their portraits in order to enhance their chance of being chosen, or if Incze sponsored the photos directly. 
Most extraordinary of all of the preparations for the 1930 competition in Szinházi élet is that found in the Christmas 1929 issue (Dec 22-28: 17-19) Incze actually persuaded Count Kuno Klebelsberg (1875-1932), the Minister of Interior and Culture for the Bethlen governement, to write an article entitled "Szépségnazionalizmus"['Beauty Nationalism'], in which he states that [female] beauty is a national treasure, just like the beauty of nature, and that foreigners who delight in the Balaton or in the hills of Buda will also delight in Hungarian women. He proceeds to explain that the national duty of beautiful womanhood is a faj kitenyésztese ['the breeding of the Hungarian race'] so that the beauty of the race survives, which is in line with the nationalistic biological politics that were also represented by Klebelsberg's close friend, Cécile Tormay and her feminist organization, MANSZ, as was previously discussed. It then seems very peculiar that Klebelsberg would promote beauty pageants while claiming that they are only immoral if the selection is not one hundred-percent honest. Klebelsberg finally praises Böske Simon, Miss Hungaria for having done a very useful national service. Klebelsberg's curious article can perhaps be understood in the context of the interwar political promotion of cultural nationalism that was created by the governing elite as a way to persuade the Entente to understand the unfairness of their treatment of the Hungarian nation and - in acknowledgement of Hungary's cultural superiority — overturn the Treaty of Trianon (Nagy 2017; Frey 2018: 76).

The nationalistic rhetoric surrounding beauty queens in the Romanian illustrated magazine, Realitate ilustrată , that sponsored the first Miss Romania contest in 1929, was even much stronger than that expressed by Klebelsberg. The winner of this contest was Magda Demetrescu, who was mentioned above in the context of the anti-Semitic incident suffered by Lisl Goldarbiter in Bucharest. Demetrescu is also of interest because Realitate ilustrată, provided many more details concerning wh a national beauty contest should be held and who would or would not be acceptable candidates, thereby shedding much light on the arguments to be made in the present article about beauty contests and nationalism. Realitate ilustrată explains that they realized what efficient propaganda it would be for the numlui de roman ['the name Romanian'] if a representative from Romania participated in the Miss Universe contest in Galveston, and they therefore asked for an invitation from the organizers. The article urges mothers "to convince their daughters to participate in the competition and not just because of the high patriotic goal it serves but also because of the possibility of victory." Unlike the Hungarian contest, in which Sándor Incze always emphasized that contestants could appear in any outfit they liked, the roles for participants in the Romanian competition were also spelled out in great detail while emphasizing that the girls must eschew all artifice (the Romanian text translated here from Catchy 2014; Gavrial 2013; and the quotes below are translated from "Un evenimet" 2015):

When invited before the jury in Bucharest, the candidates should not wear corselettes or brassieres, or have used make-up; they are obligated to parade [before the jury] in dresses that are as simple as possible so as to allow [the jury] to judge their figures. The jury takes into account perfect features as well as a beautiful figure, gracious movements and tender appearance.

The contest organizers precisely described that they wanted to elect "a type that was representative for Romanian beauty," which they qualified as either the type from Bánát "with accentuated Romanian feature," one from Bessarabia, in which one could "feel the Slavic 
influence," or one from Oltenia with "Dacian fatures" There is also a special reference to the winner of Miss Romania measuring up to Simon, aleasa Ungariei ['Hungary's chosen one']. The same quote from the organizers also stated that, "every Romanian woman being kindhearted will understand that it is her duty" to participate in the pageant and "fight to affirm Romania's primacy." The magazine also quotes a ridiculously grandiose description (attributed to the famous writer, Liviu Rebreanu) of Demetrescu's beauty:

a musical poem, a dream, a day-dream that inebriates.... Beautiful as a fairy from a fairy-tale of old, she bears in her eyes and hair the features of our race, the black [ie., that she is a brunette]. The little mouth red like a ripe cherry, a wonderful body sculpted in the finest marble, a small and nervous foot, full arms, a shining whiteness. These are the features that adorn the one that will carry the tricolor flag of Romanian beauty across the ocean.

While implying that Demetrescu should have won, the magazine also explains that she lost to Böske Simon in the Miss Europa competition because Simon was a typical representative of those ferocious Hungarian irredentists (Gavrilă 2013).

Böske Simon's victory in 1929 was such a coup for Sándor Incze that he immediately became involved with a quickly cobbled together operetta entitled Miss Europa that was based in part on selected and much-dramatized, picturesque details reported in Szinházi élet regarding Simon's life. The piece was a collaboration between Lászlo Bús Fekete (1896-1971), whose unusual name was a Hungarianized version of his original last name, Trauerschwartz, and Imre Harmath (1890?-1942), with music by Dezső Losonczy (1892-1950). Since beginning in1916 Bús Fekete also worked at Szinházi élet it was not surprising that he had the idea for the story, in which Elli, who has just won the European beauty title, is dreaming of the Riviera, including the Prince of Monaco's castle, furs and jewels and is therefore not interested in returning to her suitor, who only has to offer "Lakypuszta ... kétszáz hold szántó...tízenhat hold szöllö... egy tornyas kis kastély" ['Lakypuszta (with its) two hundred acres of tilling fields... sixteen acres of vineyards... a gabled little castle']. The story is naturally resolved with a happy end. Of the three Jewish creators of the operetta, Bús Fekete survived the Holocaust by leaving for America in 1940; Harmath perished in the labor service, and Losonczy survived, only to die in Hungary in 1950.

While sound cinema began in 1929 in Hungary, in order to attain the most benefit out of Böske Simon's victory the most popular form of popular entertainment at the time, an operetta, was quickly produced instead of a film (Heltai 2008: 239). 1929 and 1930 also marked the peak years of interest for beauty contests in Europe; in France, the first talkie was produced as a much darker version of the previous theme in the form of the melodrama, Prix de beauté (1929-1930); in English Miss Europe). Based on a script by G. W. Pabst, this work additionally featured the contribution of René Clair and was directed by the Italian, Augusto Genina. The film started out as a silent but was revised during production to become one of the first sound films. Known for her famous bob, its star, the American flapper and Hollywood startlet Louise Brooks, represented the quintessential sex symbol of the time: the vamp or femme fatale, as exemplified in her contemporary film roles which resembled Marlene Dietrich's in Der blaue Engel. In 1929 Brooks had starred in one of the last silent classics, Die Büchse von Pandora, known as Pandora's Box, or Lulu in English. Prix de beauté replayed many of the same themes from the 
previous film, including the trope of the sexually-liberated woman who comes to a bad end. The plot concerns a typist who (against her fiancé's wishes) mails photos of herself to enter the Miss France contest and not only wins that title but also the Miss Europe contest. She is subsequently courted by many wealthy men but abandons public life to marry her fiancé, only to become unhappy with this lifestyle, at which point she leaves her husband. The heroine then becomes a film star and achieves a kind of public success, but ultimately ends up shot by her jealous husband, who steals into a darkened screening-room while she is delightedly watching herself singing and dancing on film. Both Prix de beauté and Lulu were heavily censored at the time for their portrayal of sexuality, rather than any reason stemming from the fact that the protagonist is the victim of sexual violence. In both works, the fetishized female simultaneously personifies both the angst and the fascination, if not envy, of the modern woman - whether real or fantasized - who represented a threat to traditional gender norms (on Brook's films see further McCarthy 2009). Here is a photo of Brooks with her famous bobbed hair as well as an advertisement for the film:
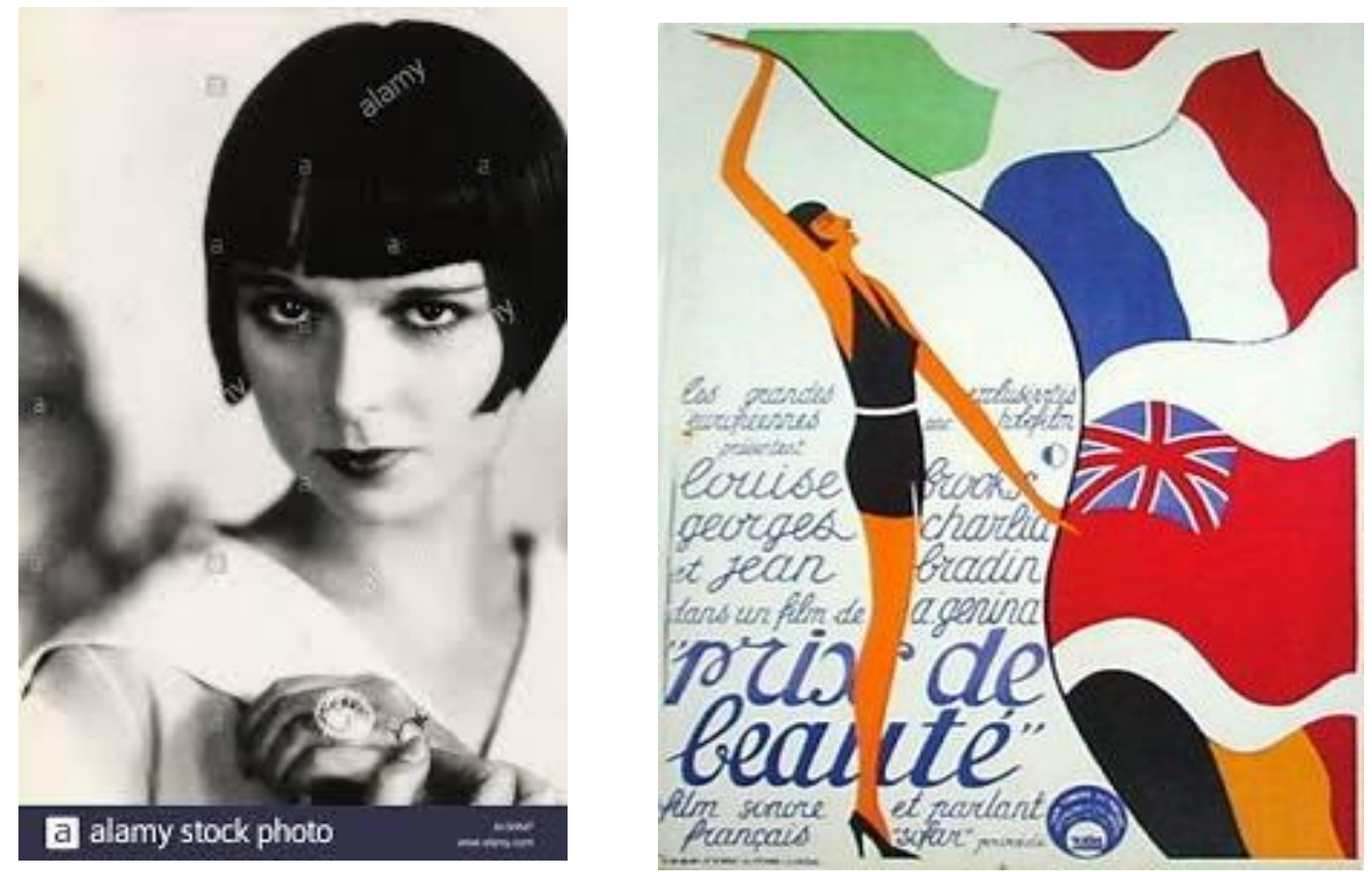


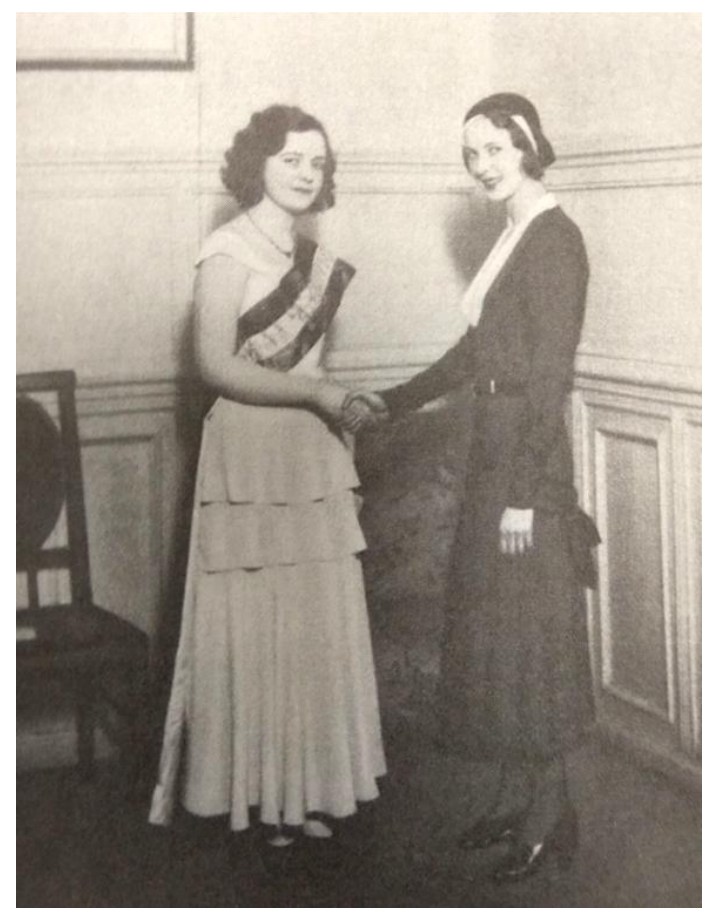

During the 1930 Misss Hungaria contest, there was such a crowd that the competition had to be moved to the Lloyd Palace. Although Magda Radó, another Jewish Hungarian, received the most votes, she was vetoed because it was felt that a Jewish girl could not be sent to the Miss Europe contest for the second year in a row. Radó was demoted to the status of first runner-up in favor of seventeen-year-old Maria Papst. A member of the jury for the next several years, it was Böske Simon who placed the sash on Papst (left). As a result of the competition, Papst immediately found a rich landowner husband, could not travel Paris to compete and had to renounce her title. In truth, a girl did not have to win to be the recipient of such luck because Incze bragged in several issues about girls who found landowner husbands (or in one case a Hungarian engineer living in the U.S.) just by having their photos published in his magazine. Perhaps it is not so surprising that some of Incze's critics called him a lánykeritö ['pimp'].

The 1931,1932, and 1933 Miss Hungaria winners were, respectively, Mária Tasnády Fekete, Ica Lampel, and Julia Gál (see further Köves 2016; Czingel 2019). However, by the time Incze announced the 1933 contest it was clear that it had lost its cachet because he only mentions that the Szinházi élet would provide the winner with elegant clothing while remaining silent about travel costs to Paris or Galveston or prize money (Szinházi élet 1933.03.46). In the previous issue of the magazine, various the opinions of various jurors regarding what the winner should be like are quoted and Simon supplies the most insipid answer: "a mai modern nö szöke, nyúlánk, könnyed. Egyénisége: internacionális ['today's modern woman is blond, slender, graceful. Her personality: international' (Szinházi élet 1933.23.2, Jan 1-7:52). Incze subsequently abandoned sponsorship altogether and instead advertised a new Korda pályázat ['Korda competition'], in collaboration with Sándor Korda (later known as Sir Alexander Korda) who was by then a film director in Hollywood and Great Britain, but had worked with Incze as film reviewer for Szinházi élet before emigrating. This was no longer a beauty contest as such but a talent contest to which both males and females could apply by sending in photos and claiming a talent or simply a resemblance to a star. The contestants, however, continued to be females in a ratio of five to one (1936.1:56-60). By 1938, there were no more major beauty contests, either in Hungary nor in the rest of Europe. In that same year Szinházi élet was forced to cease publication and Incze fled to the USA, where he remained until his death.

Because it is inevitable that some readers will ask at this point if the Jewish (albeit closeted about her origins) Zsazsa Gabor did not win the Miss Hungaria title in 1936, I must clarify that, no, this information was merely one of her many obfuscations and inventions regarding her past. Born Sári Gábor (1917 - 2016), she did become one of the two ladies-inwaiting for seventeen-year-old Júlia Gál in a contest held in 1933 (see the newsreel on the event here: https://filmhiradokonline.hu/watch.php?id=473 ). Interestingly, not only Júlia Gál, the daughter of the merchant József Goldstein, and Gábor were Jewish, but so was the other lady-in- 
waiting, seventeen-year-old Lilli Radó. (Gál was employed as a sales apprentice in the Pók lingerie and fashion store owned by Jenő Fekete, a figure very similar to Ödon Brammer in regards to building up the retail clothing business in Hungary; like Brammer, Fekete also perished in 1945.) In spite of the misinformation found in Wikipedia and elsewhere online, Zsazsa Gábor did not win the Miss Hungaria competition in 1936, and it is not even clear that there was one. Throughout her later life, including in her autobiography, she invented this story while additionally spinning a fantasy gentile background concerning an army officer father, while her actual father was a jeweler whom she and her sisters and mother left behind in Hungary. The fantasy of the gentile background was concocted on the basis of a family photo in which her father was dressed up in an officer's uniform that someone had left in hock with him (personal communication from a first cousin of the Gábor sisters, as well as from my father). Here is a photo of the then Sári Gábor in the 1933 beauty contest, where she and Lilli Radó flank Júlia Gál:

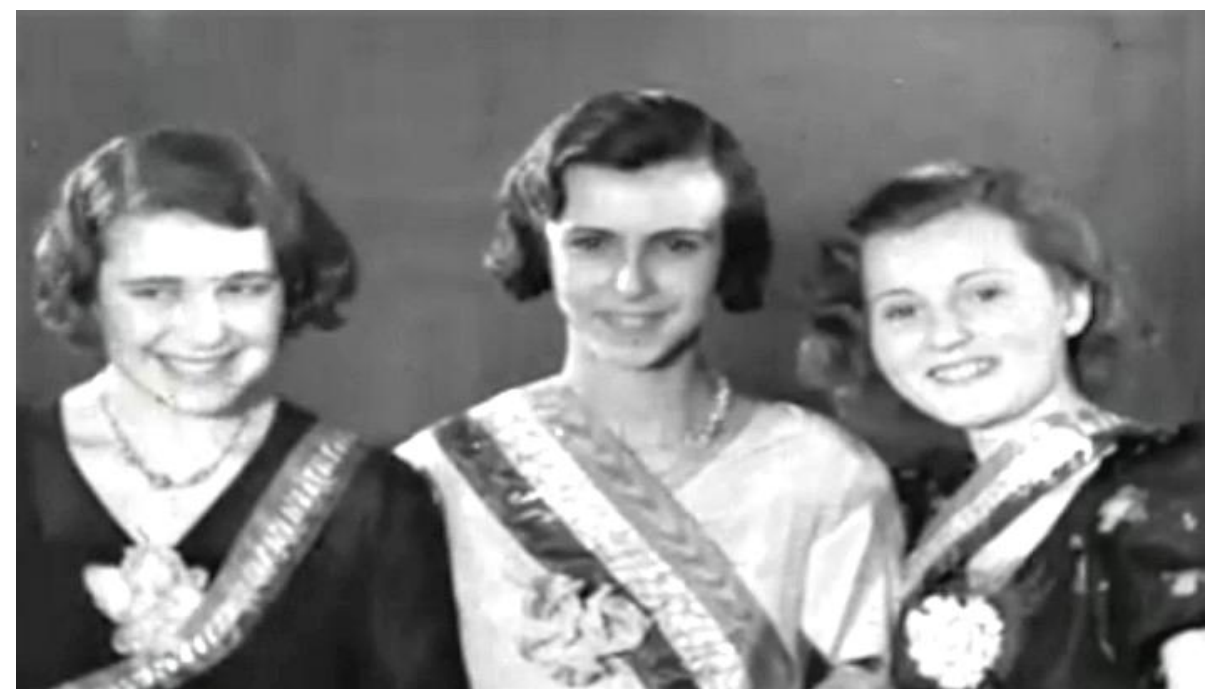

Primarily known today for his Holocaust memoir, Kilenc koffer ['Nine Suitcases'] (1946), Béla Zsolt, was actually one of the most prolific writers of the interwar period and authored wrote thirteen novels, many of which contained bitter critiques of the assimilated bourgeoisie. His A királynö családja ['The Queen's Family'] (1932) is in part a lightly fictionalized version of Böske Simon's life, as well as a critique of the new consumer beauty culture, a circumstance upon which for whatever reason even the few contemporary reviews of the novel (such as the brief, yet favorable review written by Sophie Török (1932) in Nyugat) chose not to comment. My original intent was to provide an analysis of Zsolt's novel as well, but the length of this study has made this impossible.

\section{Modernizing Tradition in the Twenties: Consumerism, Gender and the 'Modern Girl' with Bobbed Hair}

In times of cultural insecurity, there is an intensification in popular ideology of imposing strict border controls around the definition of gender, as well as those related to other categories such as race and nationality. In the aftermath of the Great War, while European society found itself experiencing rapid and profound political, economic and social instability, popular anxiety concentrated in particular on both the danger of the changing gender norm and the "Jewish 
question." Gender came to represent a microcosm of the larger postwar disarray of traditional Europe, with Jews often seen as the perpetrators of the perceived anomalies of modernity. At the same time, the development and burgeoning mass consumer culture-particularly including mass-circulation media, advertisements and department stores - was seen by many as the very essence of modernity and often of Jewishness, with women most closely identified as purchasers and Jews as mass culture entrepreneurs. (Recall in this regard the example of Böske Simon's father-in-law, the founder of one of the first fashion department stores in Hungary.) With consumerism's rise during the 1920s, mass beauty culture emerged as a lucrative field that came to codify modern femininity. It can be claimed that it is cosmetics, a symbol of the broader new commodity culture, that created the label of Modern Girl. Although the concept originated in North America, due to economic and cultural flow it quickly became a worldwide, representational category that evolved into various national and colonial incarnations, to include the flapper, vamp, and a variety of other terms across languages. Whatever the term, it came to represent both the enticements and the dangers of modernity (for further details on aspects of the Modern Girl culture see Franke 1997, Peiss 1998, von Ankum 1997, Schwartz 1998, Conor 2004, Barlow et al 2005, Stanley 2008: 1-13, 17, 27, Weinbaum et al 2008, Lotz 2009).

In contrast to the 'New Woman,' who in many contexts was her predecessor or contemporary, the Modern Girl was less often identified with directly advocating social and political reform than with ostentatiously refashioning her appearance and refining her body. She could also be variously characterized by independence, education, a career, the pursuit of pleasure and erotic or sexual indulgence; that is, with the desire to express herself in excess of conventional female roles. In fact, many descriptions of the Modern Girl revolve around fashion, with fashion functioning as a gendered metaphor of modernity while focusing on its dual function as a visual expression of women's new societal role and a regulatory discourse of femininity (Roberts 1993: 55-56; Grout 2015: 3,8). The commodities of the necessarily svelte, yet muscular Modern Girl-look included visible make-up, silk stockings, high-heeled pumps, cigarettes, a low-waisted, curve-denying yet revealing dress, cloche hats, and, most iconic of all, the boyish Bubikopf ['bobbed hair'] or mode à la garçonne (the term for the stereotype for the third sex). The haircut of flappers and the New Woman alike, the bob became the culturally prescribed modern female identity, as in the 1920s millions of women bobbed their hair (on the cultural politics of hair bobbing see Zdatny 1997, Gold 2015). Meanwhile, conservatives particularly saw the disappearance of long hair, the crown of true womanhood, as a sign of cultural decline and the masculinization of women. By 1929, some slightly more feminine versions of the bobbed style were gradually coming into fashion, as this British Pathé newsreel of hairstyles from the Miss American 1929 pageant purports to show. (It must be mentioned that the chignons shown in this film are all false hair that was clipped on when the women wore evening gowns: https://www.britishpathe.com/video/hair-styles-from-miss-america . As iconic and controversial as bobbed hair was, from the mid- and late-twenties, the increasing popularity of lipstick challenged convention with its display of sexual availability (Hackney 2010: $213 \mathrm{ff}$ ).

While the Modern Girl became the symbol of the emerging consumer culture, she could also represent everything that society found threatening and visualized discursively as a sexually promiscuous, smoking, independent working girl who appeared to disregard the roles of daughter, wife and mother. In the natalistic backlash against women that took place during the interwar years, "scientific" reports issued warnings to women concerning the threat that the physical strain caused by new professional and leisure activities would permanently damage 
their reproductive abilities (see Usborne 1992 for a critical analysis of women's experience of modernity as dominated by reproductive control). In the Hungarian scientistic racist discourse of sexuality and reproduction briefly discussed above, the noted race biologist, Lajos Méhely, contrasted two types of women: those who smoked cigarettes, visited theaters and cinemas and wore bobbed hair, and those who lived for their families and duties toward race and nation. Méhely condemned women who appeared in the public eye, even if they did so for good causes. According to many articles in the conservative press, after the loss of WWI and the trauma of Trianon traditional family structure collapsed and the confusion of gender roles ensued. These articles describe the Modern Girl as a working woman who paints her face, smokes, uses nail polish, wears stylish clothes and hats, has no interest in family life and is not szabad but szabados ['not free but licentious'] (Szabó 2009). In short, the Modern Girl epitomized the opposite of the traditional sheltered, virginal, obedient young women of the middle or upper class that the French might call the jeune fille bien élevée ['well-mannered young girl'] and the Hungarians the úrilány. This explains why it was always so important in laudatory articles about Böske Simon and Lisl Goldarbeiter to assert their good-girlhood image by repeating how modest and genteel and well-brought up they were while claiming that they had won the beauty contests without besmirching themselves with make-up.

As Mila Ganeva (2013: 114) has discussed in her study of the Miss Germania pageant in the Weimar Republic, beauty queens were contested cultural symbol; even as pageants promoted the Modern Girl as a transnational ideal of modern age, they simultaneously reinforced conservative notions regarding gender roles, with success strictly defined according to looks instead of achievement. As we have seen, in Hungary it was the Jewish magazine publisher, Sándor Incze, who essentially created Simon as the first beauty queen in order to be able to publish numerous articles and photos of her in Szinházi élet. Simon collaborated in this project by writing her mini-autobiography for his weekly, in which she extolled her finishing school, úrilány upbringing while remaining silent about her Jewishness, only to end her self-encomium by assuring her public of her wish to become only a wife to the appropriate husband. Soon after winning her Miss Europa title, she married a man whom she barely knew, after which she briefly served as a good advertisement for his family's fashion emporium. Theirs was a very traditional marriage of interest, but one that sadly ended in tragedy, firstly due to their personal incompatibility and then more deeply when the Holocaust destroyed both of their families.

A provincial Jewish girl caught between tradition and modernity, for a brief period Böske Simon could be utilized to represent the contradictory images of traditional young magyar womanhood and the international Modern Girl. In a sense, she did represent the new kind of woman that emerged during the 1920s in magazines, films and on stage: the ornamental, young, fashionable Modern Girl, a representative of Girlkultur as a fashion and cultural phenomenon. It was fitting that her persona was essentially created by Szinházi élet because it was precisely magazines that constituted the space where the interplay of the Girl as a product of the magazine and the Girl as a consumer of the same converged (on Girlkultur depicted in German magazines see Sylvester 2013). More precisely, Böske Simon was the perfect specimen for what Liz Conor (2004) has dubbed the Modern Appearing Woman, as both consumer and consumed commodity, a woman who understood self-display to be part of the quest for mobility, self-determination and sexual identity. She was svelte, youthful and sporty, played tennis and swam, danced, smoked cigarettes, was outfitted with the right kind of clothes and of course had bobbed hair, as did all beauty contestants by the late 1920s. Simon was even photographed astride a motorcycle, the 
very symbol of motorized modernity, at a time when the technology surrounding motor cars and motorcycles was strongly associated with both new forms of consumer culture as well as masculinity, and hence also in titillating fashion with Modern Girls. (On motorcycles and modernity see O'Connell 1994: 7; Disko 2016). Sponsored by the popular magazine, Motor und Sport, beauty contests were actually also held for motorcycle and automobile queens. Although Böske Simon at least was posed in proper riding attire in the photo below, girls were also often ludicrously posed as bathing beauties as they sat astride a motorcycle for titillating effect. However, what these sporty cycling photos illustrate is that while women's fashion in the 1920s often suggested an active, even athletic lifestyle, this "look" was just that, as posing was merely in the restrictive tradition of decoration that took precedence over accomplishment (Latham 2000: 96). While here Simon is at least presented respectfully in comparison to the pin-ups of the "girl on motorcycle" genre of the period, the contests soon began to deteriorate even further; by 1931 Jeanne Juilla (1909-?), Miss France and Miss Europe 1931, modelled nude in erotic boudoir cards that are still available for sale online.
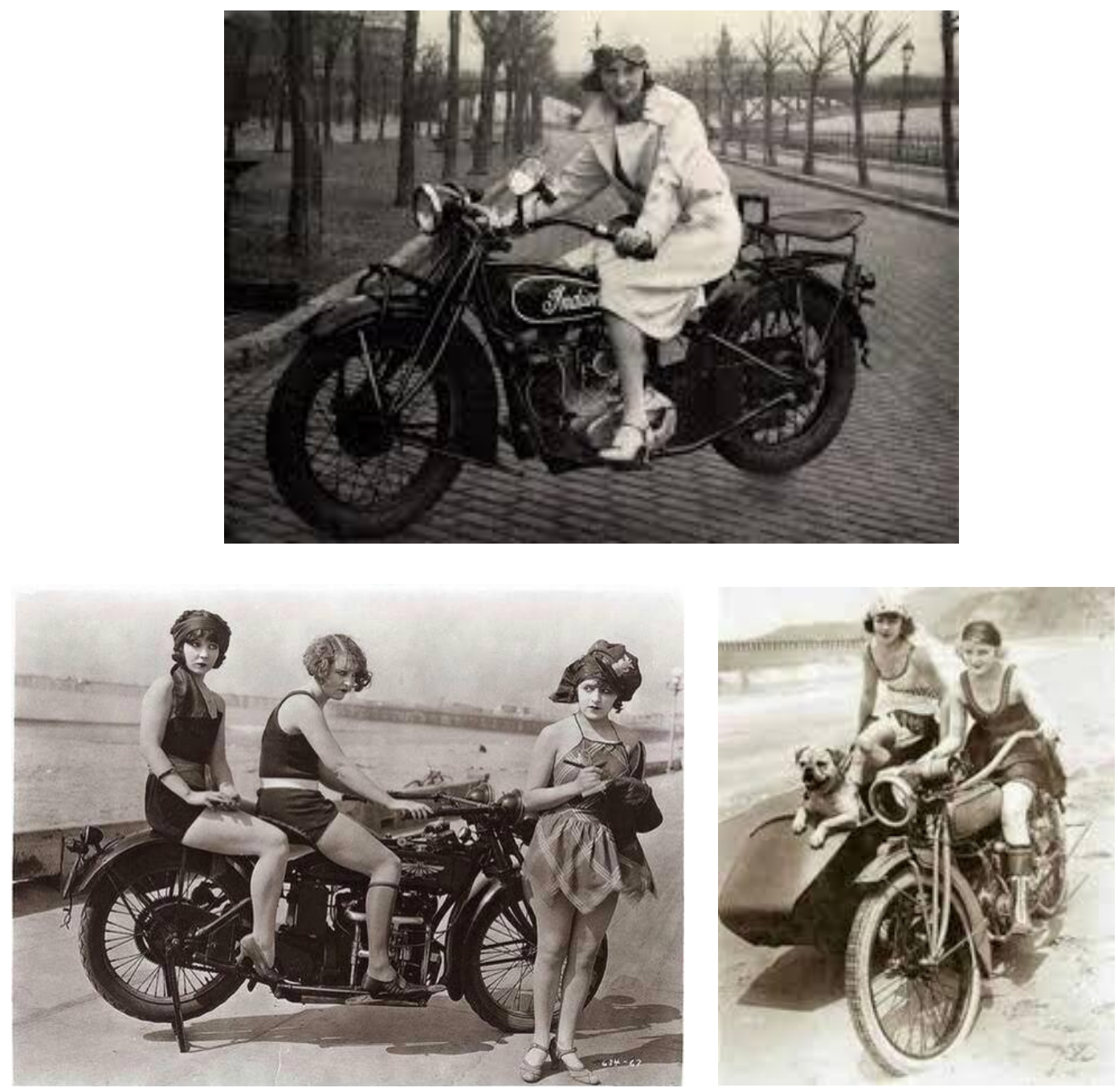
By way of demonstrating the reality of motorcycling in comparison to the photos shown above, here is what Hanni Köhler (1907-?), the most famous female motorcyclist of the time who was roughly the same age as Böske Simon at the time, looked like in a posed photo from 1929 and in another after winning a competition:
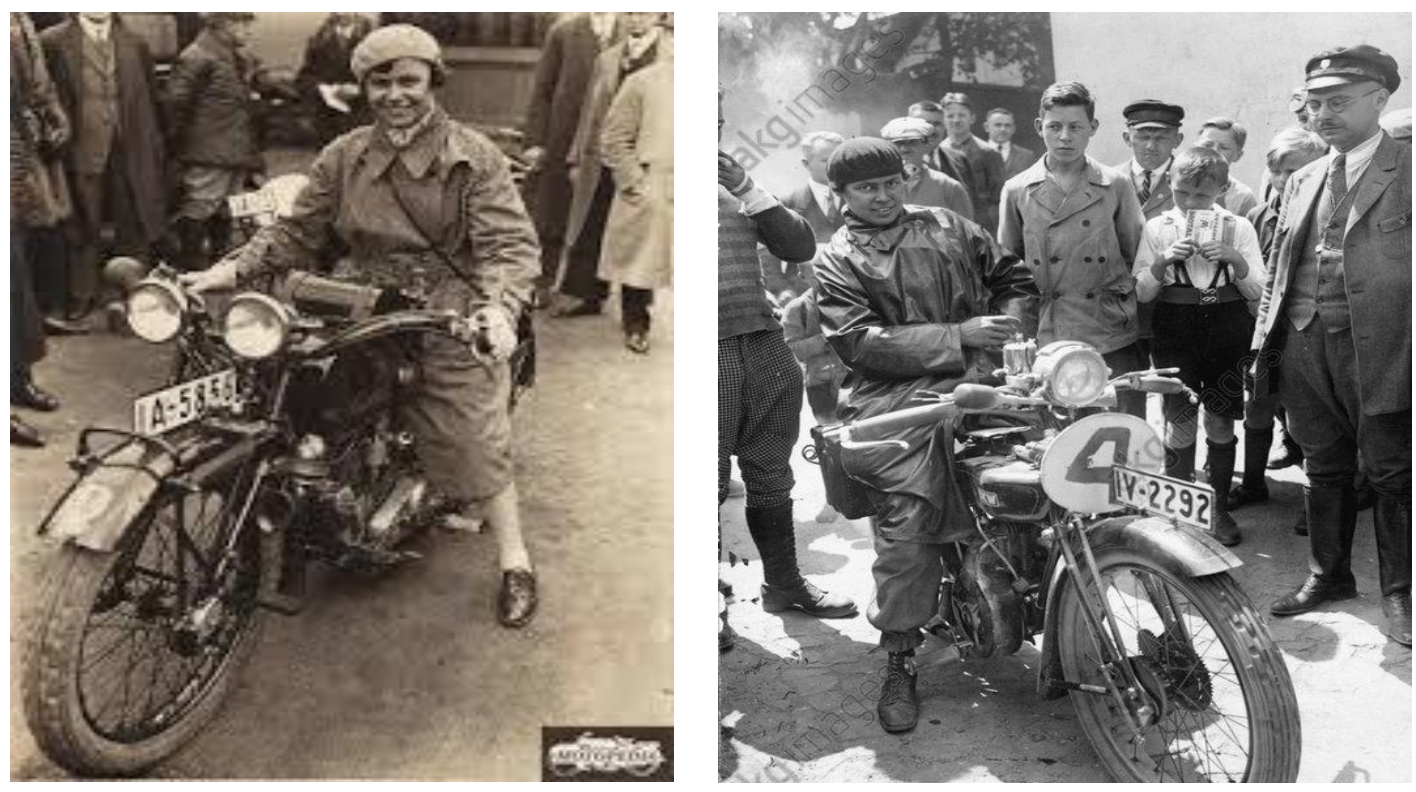

Hungary, a country where the development of urban modernity was partial and inconsistent, proved a particularly difficult place to navigate for a Jewish beauty queen. Interwar national Hungarian identity construction was complex and mainly consisted of a conservative national society in which the public sphere was defined as a Christian space that cast Jews as hostile to Hungary's interests. As Kerry Wallach (2017: 3-7) discusses in her important new book, Passing Illusions: Jewish Visibility in Weimar Germany, in this political atmosphere, the proliferation of anti-Semitic sentiments and stereotypes during and after the First World War produced a need for public models of Jewishness that were not considered objectionable. In such a political atmosphere, the issue of Jewish self-presentation was not a simple one of visibility versus invisibility, but rather comprised levels of visibility that ranged from "covering," passing, or conversion. Wallach defines covering as a less extreme, but no less consequential way of negotiating public displays and perceptions by downplaying (yet not effacing) a disfavored identity to fit into the mainstream. Using somewhat different terms from Wallach, Mary Gluck suggests in The Invisible Jewish Budapest (2016: 23) that a type of "critical crossdressing" or cultural masquerade served as a means for the Hungarian Jewish bourgeoisie to find its voice. In contrast to men, Jewish women were considered more adaptable and less recognizable; like other modern women, they, too, put themselves on display, yet also found ways to modulate. As was discussed in this study, the adjectives used to describe both Simon and Goldarbeiter as wellbrought up, genteel, refined girls simultaneously served as code for being able to pass as gentile.

The story of Böske Simon as well as all that it reveals about the clash of tradition and modernity became a part of the post-Tiranon traumatic reality. By the late 1920s, official Hungarian government policy began to focus upon the rectification of post-Trianon borders; by the summer of 1927, the Hungarian revisionist movement suddenly began to gather increasing 
momentum. In 1929 the question of whether a Jewish Miss Hungaria could, in Kuno Klebelsberg's words, represent the magyar faj, was a topic that for a brief time competed with the country's old front-page struggles. As one New York Times reporter present in Budapest wrote in her "All Hungary Astir on Treaty Revision," soon all talk only surrounded the Treaty Revision that had been proposed by Prime Minister István Bethlen (Elisabeth de Fuenktoesti 1929): "Every party seeks credit for the movement to regain former boundaries: the sensations caused by the influenza epidemic, the election of Miss Hungaria to Miss Europe, the bitter cold, the life sentence of Erdelyi, who killed his wife, and other great events are of nothing to the interest aroused in Budapest by Count Bethlen's statement concerning the revision question."

Radical critiques of beauty contests were also vehemently stated by the noted author, Joseph Roth (1930: 169-171), the Paris correspondent for the Frankfurter Zeitung at the time. Roth claimed that the whole idea for contests came from Hollywood as a means for finding replacement for popular film divas. He further criticized beauty pageants as recalling the tradition when slaves were offered at markets, at a time when women had recently shown that they could be in Parliament, lawyers and jury member. As has also been mentioned here, Roth also discussed how these contests are handled in newspapers of all political sides, including how the poor, smiling girls appear in the newsreels of every country when in fact the contests are just put together by a consortium of clothing designers and writers to find a "national type" that would then only be exported to America. Roth concludes that what is most shameful is that a film agent can play at being the mythical hero, Paris, while a hundred "queens" must lose so one can win. Roth concludes that nobody's fame lasts more than a few weeks and none of the journalists writing about the glamorous rise of a beauty from some dusty small town cares about her later life. As we have seen, Böske Simon's fate as well as that of many of those in her world was proven to be far worse than any brought about by mere anonymity.

\section{Works Consulted}

Acsády, Judit. 2014. “Diverse Constructions: Feminist and Conservative Women's Movements and Their Contribution to the (Re-)Construction of Gender Relations After the First World War." Gender and Nation in Hungary Since 1919. Special Volume, Hungarian Studies Review 41/1-2: 61-87.

Anonymous. "2016. “Az első Miss Hungary.” ['The First Miss Hungary']. Horthy-korszakot kutatók társasága 07.19 https://horthykorszak.blog.hu/2016/07/19/az_elso_miss_hungary

Anonymous. 1929. "Miss Europe. Charm as a Commercial Asset."

https://trove.nla.gov.au/newspaper/article/24256630

Ahmed-Ghosh, Huma. 2003. "Writing the Nation on the Beauty Queen's Body: Implications for a 'Hindu' Nation.” Meridiens: Feminism, Race, Transnationalism 4/1: 205-227.

ÁrvaszékiLevéltár ['Orphans'Archive'] 'https://archives.hungaricana.hu/en/lear/Arvaszeki/4005/?list=eyJxdWVyeSI6ICJEQj0o XCJBU1ZBU1pFS0lclikifQ

Banet-Weiser, Sarah. 2004. "Miss America, National Identity and the Identity Politics of Whiteness." In Watson et al: 67-92.

Banet-Weiser, Sarah. 1999. The Most Beautiful Girl in the World: Beauty Pageants and National Identity. Berkeley: U of California P. 
Vasvári, Louise O. "Böske Simon, Miss Hungaria and Miss Europa (1929): Beauty Pageants and Packaging Gender, Race, and National Identity in Interwar Hungary." Hungarian Cultural Studies. e-Journal of the American Hungarian Educators Association, Volume 12 (2019) DOI: 10.5195/ahea.2019.360

Barlow, Tani E. et al. 2005. 'The Modern Girl around the World: A Research Agenda and Preliminary Findings." Gender and History 17/2: 245-294.

Bowlby, Rachel 1985/2009. Just Looking. Consumer Culture in Dreisser, Gissing, and Zola. New York: Routledge.

Brown, Elspeth H. 2014. "The Commodification of Aesthetic Feeling: Race, Sexuality and the 1920s Stage Model." Feminist Studies 40/1: 65-97.

Burr Christina. 2013. "Beauty, Cosmetics, and Vernacular Ethnology in Weimar and Nazi Germany." Globalizing Beauty. Harmut Berghoff and Thomas Kühne, eds. New York: Palgrave MacMillan: 171-191.

Carlson, Eric G. 1998. Thinking Fascism: Sapphic Modernism and Fascist Modernity. Stanford: Standord UP.

Catchy. 2014. "Prima Miss Romaniâ - Magda Demetrescu (Concursul de frumusete, acum 85 de ani” ['First Miss Romania - Magda Demetrescu (Beauty Contest, 85 Years Ago] Feb 23. https://www.catchy.ro/prima-miss-romania-magda-demetrescu-concursul-de-frumuseteacum-85-de-ani/56152

Cohen Colleen Ballerion, Richard Wilk, and Beverly Stoeltje, eds. 1995. Beauty Queens on the Global Stage: Gender, Contests and Power. New York: Routledge.

Conor, Liz. 2004. The Spectacular Modern Woman. Female Visibility in the 1920s. Bloomington: Indiana UP.

Czingel, Szilvia. 2019. “'Nagyon szép lány, kár hogy zsidó’- Gál Júlia és az 1933-as Miss Magyarorsz'g választas" ['A Very Beautiful Girl, Too Bad She is Jewish. Júlia Gál and the 1933 Miss Hungary Contest']. Mult és Jövö 30.2: 94-109.

Disko, Sasha. 2016. The Devil's Wheels: Men and Motorcycling in the Weimar Republic. New York: Berghahn.

Franke, Lynne. 1997. "Gretchen, Girl, Garçonne? Weimar Science and Popular Culture in Search of the Ideal Woman." In von Ankum, ed.: 12-40.

Frey, David. 2018. Jews, Nazis and the Cinema of Hungary: The Tragedy of Success, 1929-1944. London: I. B. Tauris.

Fuenktoesti, Elisabeth de. 1929. "All Hungary Astir on Treaty Revision.” New York Times March 3, 1929.

Ganeva, Mila. 2013. "Miss Germany, Miss Europe, Miss Universe Beauty Pageants in Popular Media in the Weimar Republic." Globalizing Beauty: Consumerism in Body Aesthetics in the Twentieth Century. Ed. Hartmut Berghoff and Thomas Kühne. New York: Palgrave: 111-130.

Ganeva, Mila. 2009. Elegance of Spectacle in Berlin: The Gerson Fashion store and the Rise of the Modern Fashion Show." The Places and Spaces of Fashion: 1800-2007. John Potvin, ed. New York: Routledge: 121-138.

Ganeva, Mila 2003. "Fashion Photography and Women's Modernity in Weimar Germany: the Case of Yva." National Women's Studies Association Journal 15.3: 1-25.

Gavrilă, Bianca Sara. 2013. "Primului Concurs de Miss din România." ['First Miss Romania Competition'] 'ttps://adevarul.ro/locale/bistrita/foto-culisele-primului-concurs--missromania-1_51717768053c7dd83f26e495/index.html\#gallery_currentImage

Gold, David. 2015. "'Whose Hair Is It Anyway?' Bobbed Hair and the Rhetorical Fashioning of the Modern American Woman.” Peitho 17.2 https://pe1404.com/gold/wpcontent/uploads/2015/07/Gold-Bobbed-Peitho.pdf 
Vasvári, Louise O. "Böske Simon, Miss Hungaria and Miss Europa (1929): Beauty Pageants and Packaging Gender, Race, and National Identity in Interwar Hungary." Hungarian Cultural Studies. e-Journal of the American Hungarian Educators Association, Volume 12 (2019) DOI: 10.5195/ahea.2019.360

Goldschmied, István and Lajos Szarka. 2005. A keszthelyi zsidoság története 1699-2005. ['The History of Keszthely Jewry']. Keszthely: Keszthelyi Israelit Hitközség.

Grout, Kelly. 2005. The Force of Beauty: Transforming French Ideas of Femininity in the Third Republic. Baton Rouge: Louisiana State UP

Hackney, Fiona Anne Seaton. 2010. “They Opened Up a Whole New World:” Feminine Modernity and Female Imagination in Women's Magazines, 1919-1939. PhD Dissertation, Goldsmith College, University of London.

Hamlin, Kimberly A. 2004. "Bathing Suits and Backlash: The First Miss American Pageants, 1921-1927." In Watson and Martin, eds.: 27-52.

Hardt, Hanno. 1989. "Pictures for the Masses: Photography and the Rise of Popular Magazines in Weimar Germany." Communication Theory 8: 7-29.

Heltai, Gyöngyi. 2008. "Bulvárszereposztás. Női szerep- és identitásmodellek a két háború köötti operettben és szinházi sajtoban, 1920-1938.” Sic Itur Ad Astra 58: 233-268 http://atelier.org.hu/upload/category/szovegek_heltai/bulvarszereposztas.pdf

Karinthy, Frigyes. 1929. 1929. "Mister Europa. Europa legkülömb férfi példányának választása a Párizsi női-bizotság szekhelyén.” ['Mister Europe: The Selection in the Parisian Women's Council Headquarters of the Most Outstand Example of the European Male'] Szinházi élet 1929.11: 22-23.

Kerepeszki, Róbert 2014. "Nationalist Masculinity and Right-Wing Radical Student Movements in Interwar Hungary: The Case of the Turul Association." Gender and Nation in Hungary Since 1919. Special Volume, Hungarian Studies Review 41/1-2: 61-87.

Köves, József. 2016. Elfelejtett királynők ['Forgotten Queens']. Budapest: K.u.K Kiadó.

Kund, Attila. 2016. "'Duties for Her Race and Nation:' Scientistic Racist Views on Sexuality and Reproduction in 1920s Hungary." Sexualities 19/1-2: 190-210.

Kurimay, Anita. 2016. "Interrogating the Historical Revisionism of the Hungarian Right: The Queer Case of Cécile Tormay.” East European Politics and Societies 30: 10-33

Kurzweil, Edith. 2007. Full Circle: A Memoir. New York: Routledge.

Latham, Angela J. 2000. Flappers, Chorus Girls, Posing a Threat and Other Brazen

Performances of the American 1920s. Hanover: Wesleyan UP.

Latham, Angela J. 1995. "Packaging Woman: The Concurrent Rise of Beauty Pageants, Public Bathing, and Other Performances of Female "Nudity" Journal of Popular Culture 29/3: 149-167.

Lerner, Paul. 2015. Consuming Temple: Jews, Department Stores, and the Consumer Revolution in Germany, 1880-1940. Ithaca: Cornell UP.

Lotz, Lizabeth M. 2009. Leading the Life of a Modern Girl: Representations of Womanhood. In Cuban Popular Culture, 1919-1929. PhD Dissertation. Chapel Hill: U of North. Carolina $\mathrm{P}$.

McCarthy, Margaret. 2009. "Surface Sheen and Charged Bodies. Louise Brooks as Lulu in Pandora's Box." Weimar Cinema: An Essential Guide to Classic Films of the Era. Noah Isenberg, ed. New York: Columbia UP: 209-236.

Medvedev, Katalin. 2018. "A Twist in Retail: The Rise, Fall, and Re-Emergence of Budapest as a Fashion City." Fashion, Style, and Popular Culture 5/2: 185-199.

Nagy, Zsolt. 2017. Great Expectations and Interwar Realities: Hungarian Cultural Diplomacy 1918-1941). Budapest: CEU P.

New York Times. “Anti-Semites Annoy Miss Europe.” March 31, 1929. 
New York Times. “'Miss Europe' Warned Against Texas Show.” April 7, 1929: 59.

New York Times. "Miss Universe Jeered in Rumania as Too Thin; Austrian Jewish Beauty Seeks Refuge in Cathedral and Police Rescue Her." Friday Aug. 30, 1929:2.

New York Times. "A Mixed Reception for Miss Universe in Bucharest: Lisl Goldarbeiter."

September 15, 1929.

O'Connell, Sean. 1994/2007. "Motoring and Modernity." Twentieth-Century Britain: Economic,

Cultural and Social Change. Eds. Francesca Carnevali, Julie Marie Strange. London:

Routledge.

Passmore, Kevin, ed. 2003. Women, Gender, and Fascism in Europe, 1919-1945. Manchester: U of Manchester P.

Peiss, Kathy. 1998 Hope in a Jar: The Making of America's Beauty Cultures. New York: U of Pennsylvania P.

Péntek, Orsolya. 2018. A magyar foot 1840-1989. Budapest: Látóhatár Kiadó.

Portuges, Catherine. 2011. "Found Images as Witness to Central European History: A Bibó

Reader and Miss Universe 1929” Cinema's Alchemist. The Films of Péter Forgács. Bill

Nichols and Michael Renov, eds. Minneapolis: U of Minnesota P: 159-176.

Roberts, Mary Louise. 1993. "Samson and Delilah Revisited. The Politics of Fashion in 1920s

France." The American Historical Review 98/3:657-684. Repr. in The Modern Woman

Revisited: Paris Between the Wars. Whitney Chadwick, ed. New Brunswick: Rutgers UP. 2003: 65-94.

Roemer, Nils. 2013. "Photographers, Jews and the Fashioning of Women in the Weimar

Republic." Fashioning Jews: Clothing, Culture and Commerce. Leonard Greenspoon ed.

West Lafayette: Purdue UP: 99-111.

Roth, Joseph. 1930. "Die Schonheitskönigin.” Werke 2: Das journalistische Werk 1929-1939.

Ed. Klaus Westermann. Koln, 1989: [169-171]

Sara, Bianca. 2013. "Primului Concurs de Miss din România" ['First Contest of Miss Romania']

Sárai Szabó, Katalin. 2009. "Családi élet örzői, magyar református anyák, asszonyok”

['Protectors of Family Life, Hungarian Protestant Mother, Married Women'] Méfiakutato

https://mediakutato.hu/cikk/2009_01_tavasz/07_nok_reformatus_egyhazi_sajtoban

Schwartz, Vanessa. 1998. Spectacular Realities: Early Mass Culture in Fin-de-Siècle Paris.

Berkeley: U of California P.

Sólyom, András. 2004. Angelo mester fotografál ['Maestro Angelo Takes Photos'].

https://maimanohaz.blog.hu/2019/01/31/125_eve_szuletett_angelo_fotomuvesz_filmoperat or_es_divattervezo?fbclid=IwAR2HhNEtKG8Ys2CnZusQmjV8pn1TqvzXc4p_zGVGlyJ3 3AceyTLpBZY6SM

Stanley, Adam C. 2008. Modernizing Tradition: Gender and Consumerism in Interwar France and Germany. Baton Rouge: Louisiana State UP.

Stewart, Mary Lynn. 2001. For Health and Beauty: Physical Culture for Frenchwomen, 1880s1930s. Baltimore: Johns Hopkins.

Stewart, Mary Lynn, with Nancy Janovicek. 2001. "Slimming the Female Body?: Re-Evaluating Dress, Corsets and Physical Culture in France, 1890s-1930s." Fashion Theory 5/2: 173193. 
Vasvári, Louise O. "Böske Simon, Miss Hungaria and Miss Europa (1929): Beauty Pageants and Packaging Gender, Race, and National Identity in Interwar Hungary." Hungarian Cultural Studies. e-Journal of the American Hungarian Educators Association, Volume 12 (2019) DOI: 10.5195/ahea.2019.360

Sylvester, Nina. 2013. "'Before Cosmopolitan.” The Girl in German Women's Magazines." Mapping the Magazine: Comparative Studies in Magazine Journalism. Tim Holmes, ed. New York: Taylor and Francis: 550-554.

Szapor, Judith. 2017. Hungarian Woman's Activism In the Wake of the First World War. London: Bloombury.

Szarka, Lajos. 2017.. Simon Böske naplója ['The Diary of Böske Simon']. Keszthely: Immánuel Magyar-Izraeli Baráti Társaság.

Szarka Lajos. 2010. "Simon Böske az Magyarország szépe.”['Böske Simon, the First Beauty of Hungary']. Mazsihisz 01.02 http://mazsihisz.hu/simon-boske-az-elso-magyarorszag-szepe2469.html [Identical article in Hetek 2009. 12.18

http://www.hetek.hu/hatter/200912/az_elso_miss_hungaria

Sylvester, Nina. 2008. "The Girl in German Women's Magazines in the 1920's" Mapping the Magazine. Comparative Studies in Magazine Journalism. Tim Holmes, ed. New York: Routledge: 29-33.

Tenczer, Márton. 2000. Szerelmem, Lisl. Budapest: Magus Kiadó.

Tetorka, Elyce. 2010. “The Fashion Model: 1920s.” The Conde Nast Story Blog https://condenaststore.wordpress.com/2010/05/04/the-fashion-model-1920s/

Thoms, Ulrike. 2013. "Consuming Bodies: The Commodification and Technification of Slenderness in the Twentieth Century." Globalizing Beauty: Consumerism and Body Aesthetic in the Twentieth Century. Hartmut Berghoff and Thomas Kühne, eds. New York: Palgrave MacMillan: 41-60.

Török, Sophie. 1932. “A királynő családja. Zsolt Béla regénye.” Nyugat 18.

Turda, Marius, and Paul Weidling, eds. 2007. Blood and Homeland: Eugenics and Racial Nationalism in Central and Southeast Europe. Budapest: Central European P.

"Un eveniment din anul 1929 -primul concurs "Miss România" ['An Event of 1929 -The First

https://cersipamantromanesc.wordpress.com/2015/04/29/eveniment-in-anul-1929-primulconcurs-miss-romania-video/

Usborne, Cornelia. 1992. The Politics of the Body in Weimar Germany: Women's Reproductive Rights and Duties London: Macmillan.

Vámos, Éva. 2007. “Atomic kavéföző.” Élet és tudomány 62/20: 638.

Várdy, Steven Béla. 1983. The Impact of Trianon Upon Hungary and the Hungarian Mind: The Nature of Interwar Hungarian Irrendentism.” Hungarian Studies Review 10/1: 21-42.

Velmet, Aro. 2014. "Beauty and Big Business: Gender, Race, and Civilizational Decline in French Beauty Pageants, 1920-37." French History 28.1: 66-91.

von Ankum, Katharina, ed. 1997. Women in the Metropolis: Gender and Modernity in Weimar Culture. Berkeley: U of California P.

Waleffe, Maurice de. 1947. Quand Paris était un paradis. Mémoires 1900-1939. Paris: Editions de Noël.

Wallach, Kerry. 2017. Passing Illusions. Jewish Visibility in Weimar Germany. Ann Arbor: U of Michigan P.

Wallach, Kerry. 2013. "Weimar Jewish Chic: Jewish Women and Fashion in 1920's Germany." Fashioning Jews. Leonard J. Greenspoon, ed. West Lafayette: Purdue UP: 114-121.

Walton, Whitney. 2005. "American Girls and French Jeunes Filles: Negotiation National Identities in Interwar France." Gender and History 17/2: 325-353. 
Warren, Lansing. 1929. 'Beauty in Europe is Now Standardized; Contest Queens of Seventeen Nations Look Alike." New York Times Sunday, Feb. 17: 3.

Watson, Elwood, Darcy Martin, Ronald Ed Watson, eds. 2004. 'There She Is, Miss America:' The Politics of Sex, Beauty, and Race in America's Most Famous Pageant. New York: Palgrave MacMillan.

Weaver, Eric Beckett. 2006. National Narcissism: The Cult and Intersection of Nationalist Gender in Hungary. Oxford: Peter Lang.

Webb, Arthur. 1929. "Ireland to Have No Entry in Beauty Show at Galveston, Owing to the Clergy's Protest.” New York Times March 17.

Weinbaum, Alys Eve et al. 2008. The Modern Girl Around the World. Consumption, Modernity, and Globalization. Durham: Duke UP.

Zdatny, Steven. 1997. "The Boyish Look and the Liberated Woman: The Politics and Aesthetics of Women's Hair Styles." Fashion Theory 1.4: 367-398.

Zox-Weaver, Annalisa. 2011. Women, Modernism and Fascism. Cambridge: Cambridge UP. 